\title{
Three Economic Myths about Ageing: Participation, Immigration and Infrastructure
}

\section{MACROBUSINESS CONSULTING}

Dr Cameron K. Murray and Leith van Onselen April 2019

A policy research report prepared for Sustainable Australia.

Population ageing due to longevity is one of the greatest successes of the modern era. However, it is widely thought to dramatically reduce workforce participation and overall output resulting in significant economic costs.

This widely held view is wrong. Ageing countries have higher economic growth and the improved health and longevity of older people increases their economic contributions.

High immigration is also thought to combat population ageing and be a remedy for these non-existent costs of ageing.

This is wrong. Low immigration can affect the age structure by helping to stabilise the population, but high immigration has almost no long-run effect besides increasing the total population level. This creates bigger problems in the future.

It is also widely thought that simply investing in infrastructure will accommodate high immigration and population growth at little cost.

This too is wrong.

Diseconomies of scale are a feature of rapid infrastructure expansion due to (1) the need to retrofit built-up cities, (2) the dilution of irreplaceable natural resources, and (3) the scale of investment relative to the stock of infrastructure.

This ageing-immigration-infrastructure story is wrong on all three of its major points. Population ageing should be seen as the successful result of improvements in medical and health practices that have improved longevity and fostered a long-lived and economically productive society. 


\section{Executive summary}

\section{Key research findings}

- Population ageing is a successful result of efforts to improve longevity.

- Countries with older populations maintain high workforce participation, are more productive, and grow faster economically.

- Ageing does not lower workforce participation in general. Since 2012 there have been more full-time workers aged over 65 than under 20 .

- Low net immigration of between 50-80,000 permanent migrants per year can alter the age structure over the long-term by stabilising the population.

- Low net immigration increases GDP per capita and wage growth.

- High net immigration above this 50-80,000 amount has almost no additional effect on changing the age structure and simply increases the total population.

- Most of the increase in permanent migration since the early 2000 s has been through the skilled migration program.

- This program primarily benefits the migrants themselves and increases wage competition for other workers.

- A focus on skilled immigration fosters a "brain drain" from developing countries, reducing human welfare.

- There is a real economic cost to high population growth due to the diseconomies of scale inherent in rapid infrastructure expansion.

- There is a real cost from environmental degradation due to development to accommodate much higher populations.

- The high costs of population growth are often ignored, as immigration policy is a federal matter, while infrastructure provision is predominantly a state and council matter.

- Population growth in general dilutes ownership of our environmental endowments, mineral wealth, fisheries, wildlife, and national parks.

- The political capital and resource devoted to managing high growth have an opportunity cost in terms of solving other social problems such as homelessness, indigenous disadvantage, mental health, and other social services.

\section{Policy recommendations}

- Reframe ageing as the economic success story that it is.

- Reframe immigration as an environmental and ethical choice, not an economic necessity.

- Lower overall net immigration to the $50-80,000$ range by mainly targeting skilled visas. This can largely be achieved by increasing the minimum salary for skilled migrants to $150 \%$ of the average full-time salary, or $\$ 129,900$. This desirable net immigration range can be achieved while having a slightly higher permanent intake of around 80-90,000 per year, as permanent departures will reduce the net effect while still maintaining the optimal target range.

- Adopt systems for infrastructure planning and provision that clarify the expected cost of new public and essential services, and ensure upgrades keep pace with city growth for the benefit of existing and new residents. 


\section{Table of Contents}

Executive summary 1

Key research findings 1

Policy recommendations 1

Background 3

Wrong thing \#1: Ageing and the workforce 4

The participation rate 5

A temporary demographic trend 5

$\begin{array}{ll}\text { Higher participation of over 65s and lower youth participation } & 6\end{array}$

$\begin{array}{ll}\text { Fewer dependent children } & 7\end{array}$

More competition for workers 8

$\begin{array}{lr}\text { Ageing helps economic growth } & 10\end{array}$

$\begin{array}{ll}\text { Informal economic contributions } & 10\end{array}$

Wrong thing \#2: The high immigration non-solution 12

Low immigration reduces ageing, high immigration boosts population 13

$\begin{array}{ll}\text { What about skills shortages? } & 15\end{array}$

$\begin{array}{ll}\text { A shortage and a falling price? } & 18\end{array}$

$\begin{array}{ll}\text { Who benefits? } & 20\end{array}$

Wrong thing \#3: The infrastructure costs of high growth 21

$\begin{array}{ll}\text { Diseconomies of scale } & 22\end{array}$

$\begin{array}{ll}\text { Diluting our environmental endowments } & 25\end{array}$

The scale of necessary infrastructure investment is immense 26

$\begin{array}{ll}\text { Opportunity costs of political capital } & 28\end{array}$

$\begin{array}{ll}\text { Policy recommendations } & 29\end{array}$

Appendix A: The growth lobby behind a 'Big Australia' 30

$\begin{array}{ll}\text { Appendix B: Economists on high growth infrastructure costs } & 31\end{array}$

Appendix C: Indicative costs of services (capital-widening) 32

Hospitals 32

Childcare, schools, aged care, public transport $\quad 32$

Appendix D: How to fairly lower the immigration intake 33

Reduce the intake of both permanent and temporary skilled migrants 33

Reduce the intake of parental visas under the family stream 34

Leave the humanitarian intake unchanged 35 


\section{Background}

The easiest way to make a nation's population younger is to adopt policies that ensure people die sooner, such as by curtailing access to medical treatments. If you believe that population ageing creates enormous economic costs, as many prominent thinkers do, then our investments in medical research over the past century may have been an economically misguided affair.

Yet this is not the preferred policy of the many interest groups who use ageing as a fear campaign to promote their political objectives. Instead they promote high immigration as the policy tool of choice to combat population ageing.

Unfortunately for them, all the available evidence shows that high immigration rates do not significantly change the population age structure over the long-term compared to low rates. High immigration just increases the total population size. That the proposed solution does not solve their alleged problem raises questions about the true motives behind such claims.

The overarching story told about the economic merits of high immigration is that population ageing is costly, immigration stops population ageing, and simply ratcheting up infrastructure investment can accommodate high immigration at very low cost. But this ageing-immigration-infrastructure story is wrong on three fronts.

1. An ageing population is not a less productive one even though it is claimed to be. Countries with older populations maintain high workforce participation, are more productive, and grow faster economically. Although ageing means more retirementage people, retirement ages are not fixed. There is also a countervailing effect of fewer children who are also dependents, a point almost universally ignored.

2. High immigration does not significantly change the population age structure compared to low immigration rates of around 50,000 per year. Instead it mostly changes the total population size. This is primarily because ageing is a function of people living longer and immigrants themselves age at exactly the same rate as everyone else.

3. High immigration imposes significant costs to incumbent residents from the dilution of access to existing natural resources and infrastructure, and the diseconomies of scale inherent in rapid infrastructure expansion in already-developed cities.

Alongside faux concerns around population ageing, vested interests have demanded a strong intake of skilled migrants on the false grounds that Australia is experiencing pervasive skills shortages.

This report examines these three economic claims about ageing, the evidence against them, and suggests policies that would capitalise on the economic benefits arising from an older and more stable population. It shows that immigration policy should not be crafted based on these three incorrect assumptions. Instead, it should be crafted to reflect community desires for levels of immigration that is ethical and environmentally and economically sustainable. 


\title{
Wrong thing \#1: Ageing and the workforce
}

\author{
Australia's ageing population means there will be a big increase in \\ numbers of the aged relative to numbers of workers. ${ }^{1}$
}

Fear about the economic cost of ageing are common across the political spectrum. The main story told is that an older population will lead to a reduction in the labour force participation rate (LFPR), or the number of working people compared to the total population. ${ }^{2}$ All else being equal, a declining LFPR is thought to be an economic problem because it means that the output of each worker must be shared with more non-workers in the population. ${ }^{3}$

Whether such a trend is economically significant depends on the degree to which 'all else being equal' holds in reality. It also depends on the underlying causes of the ageing trend, and thus the implicit reference point. For example, a family with two working parents might decide that when one of their incomes increases that the other parent can reduce their work to part-time. This has the effect of increasing total family leisure time and is an economic benefit resulting from the family's increased income. But if your reference point is a situation where both parents continue to work full-time, then this choice can be framed as an economic cost. What determines whether this is really an economic cost or benefit rest on the desirability of leisure time. If the family desires leisure above more income, this is a benefit. At a national level the same is true. If, as a community, we decide that retirement is a leisure time we all desire more than higher incomes, then more retirement is an economic benefit.

In this section we look at the evidence for the claim that population ageing is economically costly. In particular, we focus on the various demographic and market interactions that mean many of the 'all else equal' assumptions that underpin claims that ageing is costly are invalid.

In short, the long-term trend of LFPR for older age groups is rising, but this effect is masked by the unwinding of a temporary blip in LFPR arising from both baby-boomers and their children being of working age at the same time. During this temporary unwinding period, there will be greater competition for workers across the economy. In turn, this will likely boost wages-something policy-makers have been hoping for while enacting policies that achieve the opposite effect.

Fewer children is another feature of an ageing population, which reduces the number of high-needs non-working dependents. This story looks much different to the one that paints ageing as economically costly.

\footnotetext{
${ }^{1}$ Deloitte. (2012). Increasing participation among older workers: The grey army advances. Report prepared for the Australian Human Rights Commission https://www.humanrights.gov.au/sites/default/files/document/publication/deloitte-matureage-participation-research.pdf

${ }^{2}$ There are many metrics that come under this name, or the name Employment to Population Ratio. Despite their names, these metrics usually do not use total population as the denominator. Instead, they usually use the population aged over 15 only. This makes little sense, and children are also dependents, and an ageing population necessarily has relatively fewer children.

${ }^{3}$ Though it is not clear what an optimal LFPR is, as lower rates increase leisure time throughout the lifetime. Indeed, labour force participation can also be thought of in terms of work days per year, rather than worker per year. See Murray, C. (2019). Using economics to justify our fears. Fresh Economic Thinking, Blogpost. https://www.fresheconomicthinking.com/2019/02/using-economics-to-justify-our-fears.html
} 


\section{MACROBUSINESS CONSULTING}

\section{The participation rate}

In Figure 1 we show the total LFPR in Australia since 1966 and the pre-2000 and post2000 averages. Pre-2000 there were 44 people in the formal workforce out of every 100 people in the population. This increased to around 50 in the 2000 s.

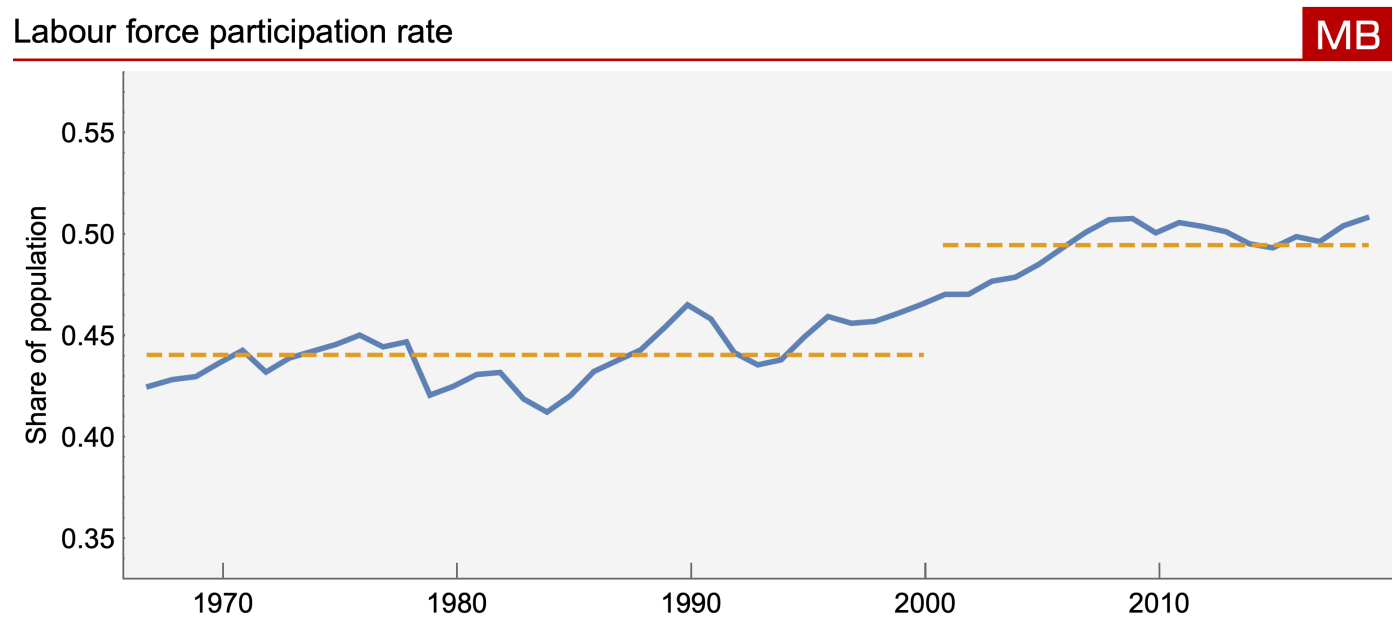

Figure 1: Participation rate (labour force/total population), Australia, 1966-2018. ${ }^{4}$

This pattern is reflective of global trends. Canada, New Zealand, the United States and the United Kingdom, all have seen increasing total participation rates since 2000 , with their current workforce making up approximately $50 \%$ of the population. ${ }^{5}$

\section{A temporary demographic trend}

What is usually ignored in the ageing-immigration-infrastructure story is that the boost in labour force participation observed since 2000 is largely the result of a temporary boost in relative size of the population aged between 15 and 64. The post WWII baby-boom coupled with the immigration boom of the period created a bulge in the age structure of the population born between 1945 and 1964. On the left panel of Figure 2 we can see that this abnormally large generation was in their prime working ages (their 30 s and 40 s) in the early 1990s. They were also in their prime child-rearing ages, and there was a growing number of younger children born in that period, often referred to as the babyboomer echo. ${ }^{6}$ By the 2010s, the children of the baby-boomers, the echo, were of working age at the same time as their parents who had not yet reached age 65 . Combined with the effect of a rapid increase in immigration since 2006, this period contained two population bulges within the working age range (right panel of Figure 2), temporarily increasing the LFPR rate metrics.

In Figure 2 the relative decline in the child population from 1993 to 2018 is clearly visible. This is an automatic outcome of an ageing population, counterbalancing much of the increase in old-age dependency at the top of the pyramid with a reduction in youth-

\footnotetext{
${ }^{4}$ ABS. (2019). 6202.0 Labour Force, Australia. http://www.abs.gov.au/ausstats/abs@.nsf/mf/6202.0 and ABS. (2018) 3101.0 Australian Demographic Statistics. http://www.abs.gov.au/AUSSTATS/abs@.nsf/cat/3101.0

${ }^{5}$ OECD. (2018). Labour Force Participation Rate. https://data.oecd.org/emp/labour-force-participation-rate.htm

${ }^{6}$ ABS. (2012). 4102.0 - Australian Social Trends, 2004. http://www.abs.gov.au/Ausstats/abs@.nsf/cat/4102.0
} 


\section{MACROBUSINESS CONSULTING}

dependency at the bottom. Children are highly dependent on the current workforce to cater for their high needs, particularly in terms of healthcare and education.

Like the proverbial 'pig in the python', the temporary boost to the working-age share of the population caused by demographic events that began more than half a century ago will inevitably unwind.

AUS Population Pyramid ('000s)

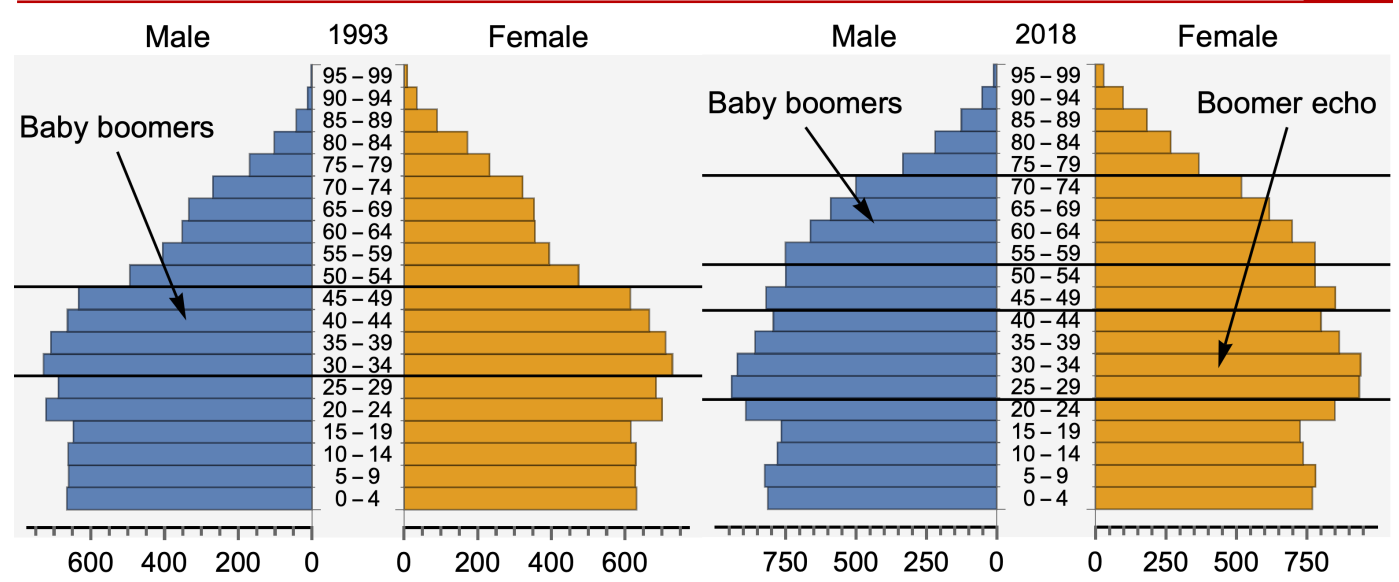

Figure 2: Population pyramids before/after baby-boomer echo in the workforce

\section{Higher participation of over 65s and lower youth participation}

Beneath this temporary pattern in the population age structure is a longer-term trend emerging in the way people contribute to economic activity throughout their lifetimes. As people live longer, and are healthier at older ages, they remain much more economically active at these older ages. In addition, younger adults are spending more time in education and less time in the workforce.

This translates into higher workforce participation of the over 65 age cohort, and a lower participation of those in the 15-19 age cohort. This trend is global ${ }^{7}$ and was acknowledged by Reserve Bank of Australia (RBA) researchers as a key factor to consider in the economic analysis of ageing.

...while ageing will put downward pressure on participation rates in all advanced economies, increases in cohort-specific participation rates could largely offset this. ${ }^{8}$

For example, the LFPR of men aged 60 to 64 increased from $45 \%$ to $60 \%$ in the 15 years between 1996 and 2011, while the participation rate for all persons over 65 has nearly tripled in the past 20 years to be nearly $15 \%$ at the end of $2018 .^{9}$

At the same time, the participation of those aged 15-19 years has shifted away from fulltime work to casual work, with only $10 \%$ in full-time work, down from $40 \%$ in the early

\footnotetext{
${ }^{7}$ Mojon, B and R. Ragot. (2019). Can an ageing workforce explain low inflation? Bank for International Settlements. https://www.bis.org/publ/work776.htm

${ }^{8}$ Brown, A. and R. Guttman. (2017). Ageing and Labour Supply in Advanced Economies. RBA Bulletin. December Quarter 2017 https://www.rba.gov.au/publications/bulletin/2017/dec/5.html

${ }^{9}$ ABS. (2019). 6202.0 Labour Force, Australia. http://www.abs.gov.au/AUSSTATS/abs@.nsf/cat/6202.0
} 


\section{MACROBUSINESS CONSULTING}

1980s (as seen in the left panel of Figure 3). Since 2012, there have been more full-time workers older than 65 than under 19 in Australia, and nearly as many total workers including part-time and casual (right panel of Figure 3).

Upwards shift of workforce age
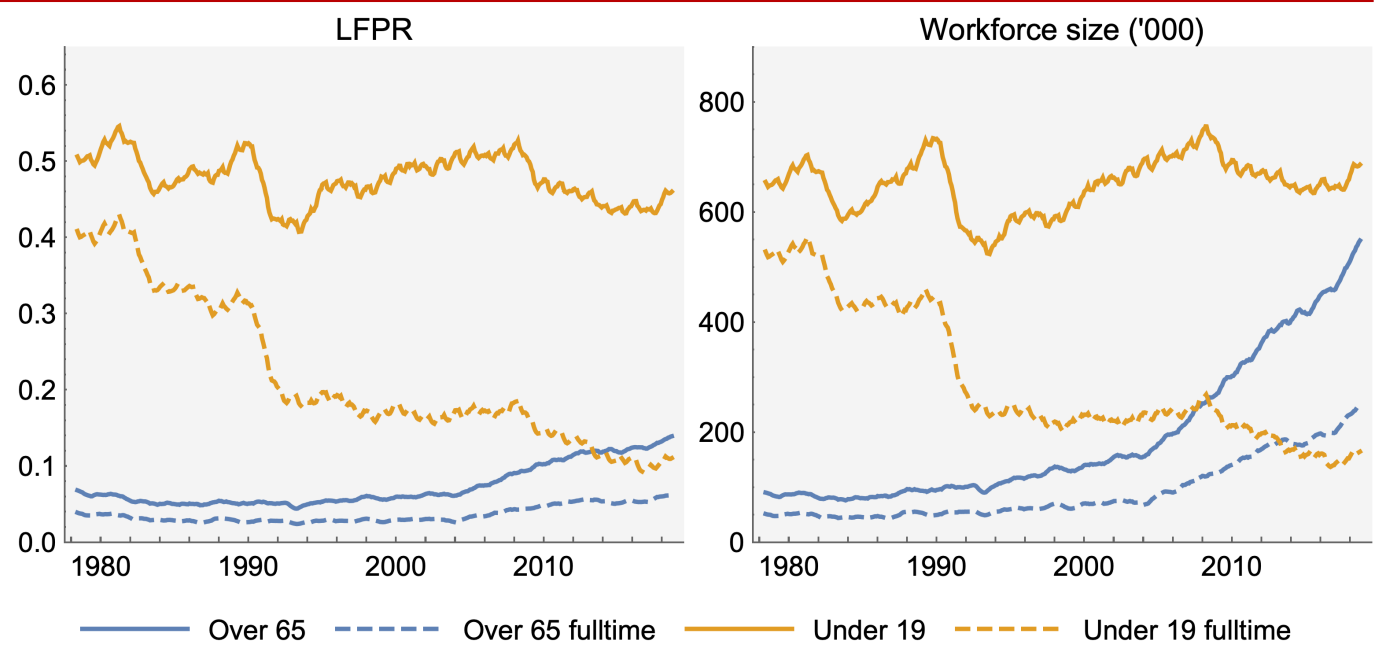

Figure 3: Participation of people over 65 years old and $15-19$ years old ${ }^{10}$

Unlike the temporary boost to the working age population due to the post-war baby/immigration boom, this shift towards working later is unlikely to be temporary, and something that needs to be expressly acknowledged in any analysis of the long-term economic effects of ageing, even though it is typically ignored.

...economic models typically assume that the proportion of people employed in each age cohort (the 'age-specific workforce participation rate') will remain unchanged regardless of changes in a society's age structure, locking the size of the workforce to the relative size of age cohorts. $^{11}$

\section{Fewer dependent children}

Concerns about the effect of ageing at the top of the population pyramid usually ignore the counterbalancing effect on dependency at the bottom of the pyramid. Children are the other major cohort of dependents in a nation, requiring many resources to be devoted to their care, health, and education. Often these costs are not considered to be important as they are mostly borne by parents rather than through public funding. ${ }^{12}$

While the elderly have high healthcare needs, care and education needs are relatively high for children. More children necessarily reallocate more workers into caring roles, whether it is parental care in the home, or formal child-care. Parental care removes one parent from the potential workforce when they dedicate their time to child-rearing. In

\footnotetext{
${ }^{10}$ ABS. (2019). 6202.0 Labour Force, Australia. http://www.abs.gov.au/AUSSTATS/abs@.nsf/cat/6202.0

${ }^{11}$ Götmark, F., Cafaro, P. and O’Sullivan, J., 2018. Aging Human Populations: Good for Us, Good for the Earth. Trends in Ecology \& Evolution. p853. https://www.cell.com/trends/ecology-evolution/fulltext/S0169-5347(18)30208-8

12 The 2002 Intergenerational Report, for example, was focussed on the effect of ageing on government budgets. But this is a very incomplete picture of the total economic effect of ageing. https://treasury.gov.au/publication/2002-igr/
} 


\section{MACROBUSINESS CONSULTING}

formal childcare (and even after-school-care, both of which are growing ${ }^{13}$ ), statutory ratios mean that one non-parent worker is dedicated to care for every seven children on average.${ }^{14} \mathrm{~A}$ relative decline in the care needs of children will offset much of the increased care needs of the elderly in an ageing.

We can see in the left panel of Figure 4 this offsetting effect of declining youthdependency in an ageing population. In the left panel the cut-off ages are the traditional levels of below 15 for children, and above 65 for old-age. We can see that until 2010, all of the increase in the old-age-dependency ratio was offset by the decline in the youthdependency ratio. However, as noted above, these ages no longer reflect the modern workforce structure. We therefore also include in the right panel of Figure 4 the same measures by with the age cut-offs of 20 and 70 years. Using this measure, total dependency is slightly higher overall due to the population aged 15-19 being slightly higher than the population aged 65-69, but the recent dependency increase is less pronounced.

Composition of dependency (youth and old-aged)

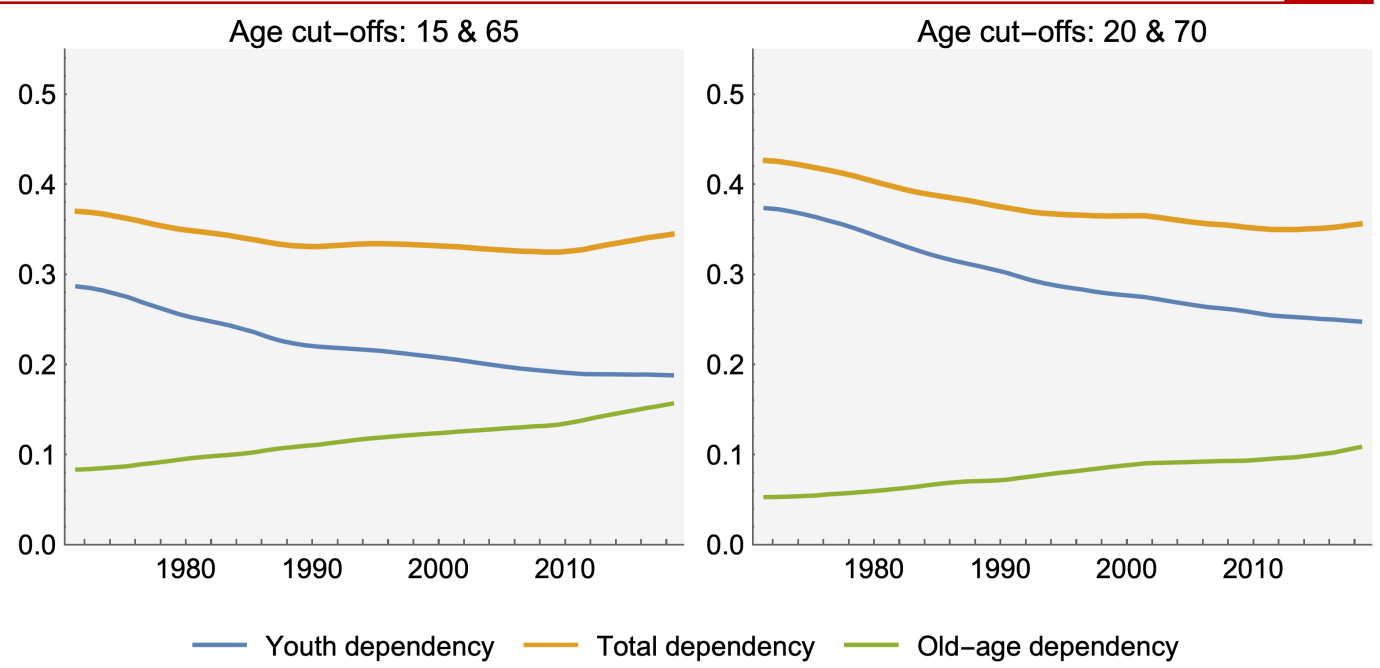

Figure 4: Australia's youth, aged, and total dependency ${ }^{15}$

Any discussion on the economics of ageing must take into account the offsetting effects on a lower youth dependency ratio and incorporate all economic effects of ageing, not just the effect on government budgets going to the top of the age pyramid.

\section{More competition for workers}

Regardless of the net long-term effect of ageing on the LFPR, the argument that a larger workforce is unambiguously good also needs careful consideration. Alongside rapid

\footnotetext{
${ }^{13}$ ABS. (2017). 4402.0 - Childhood Education and Care, Australia, June 2017. http://www.abs.gov.au/ausstats/abs@.nsf/Latestproducts/4402.0Main\%20Features1June\%202017

${ }^{14}$ Applying the mean statutory ratio of seven children per carer for children aged under 5 . https://www.acecqa.gov.au/nqf/educator-to-child-ratios

${ }^{15}$ ABS. (2018). 3101.0 Australian Demographic Statistics. Table 59. http://www.abs.gov.au/ausstats/abs@.nsf/cat/3101.0
} 


\section{MACROBUSINESS CONSULTING}

population growth over more than a decade, real wages for Australian workers have stagnated. ${ }^{16}$

A declining workforce can only boost wages, since employers will be required to compete harder for available workers. This view was confirmed recently by the RBA, which noted that "subdued trend growth in labour supply" would "tighten the labour market" and "would put upward pressure on wages."17

In fact, growing wages would likely increase participation by attracting non-workers into the workforce at all ages and stimulate productivity-enhancing investments in automation.

... that tightening labor markets will recruit people who are currently not working, by offering them better terms of employment or addressing their barriers to access, while also driving productivity gains through greater investment in staff and equipment. ${ }^{18}$

These effects appear to be at play in the experience of ageing globally. Figure 5 plots Australia alongside its peer nations in terms of old-age dependency (share of population over age 65) and total LFPR (total workforce divided by total population). The experience of these peer nations is that even a doubling of the old-age-dependency ratio can be accommodated without noticeably reducing the relative size of the workforce.

Population ageing and LFPR in peer nations

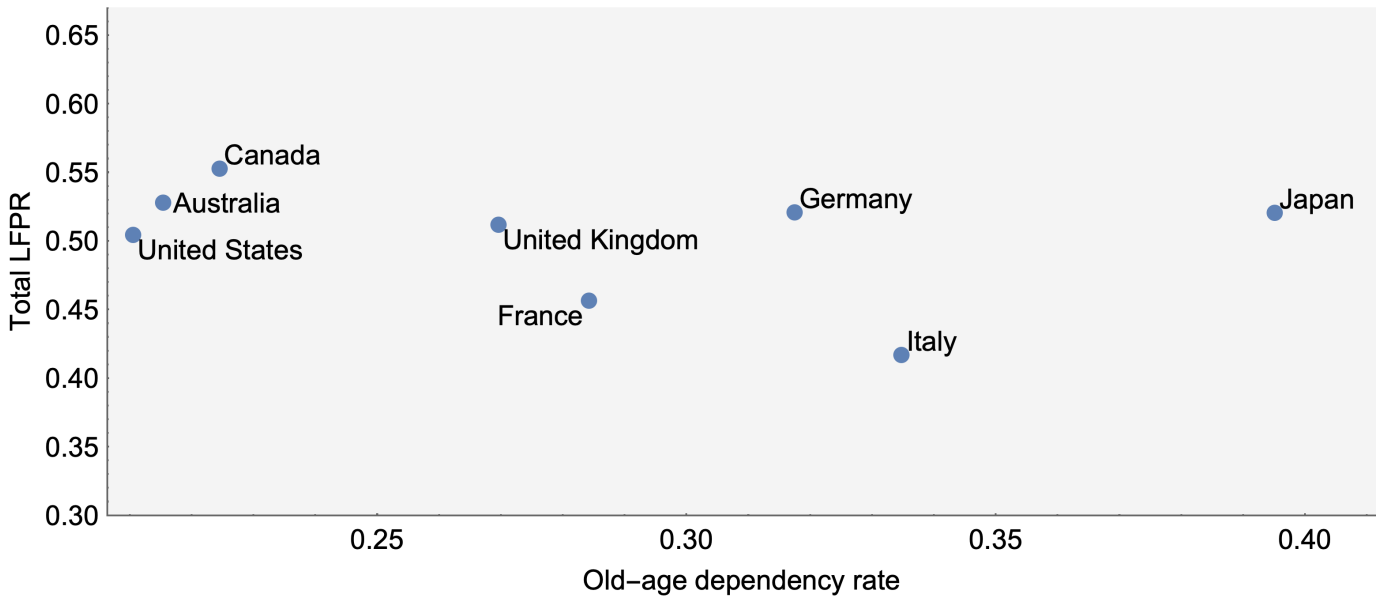

Figure 5: Global relationship between old-age dependency rates and LFPR ${ }^{19}$

As the temporary post-war baby boom/immigration wave washes through over the next decade workers are likely to finally see increasing bargaining power over wages, though the long-term prospect is for a flat LFPR.

\footnotetext{
${ }^{16}$ Van Onselen, L. (2019). Aussie real household disposable income stuck for seven long years. https://www.macrobusiness.com.au/2019/03/aussie-real-household-disposable-income-stuck-for-seven-long-years/

${ }^{17}$ Brown, A. and R. Guttman. (2017). Ageing and Labour Supply in Advanced Economies. RBA Bulletin. December Quarter 2017 https://www.rba.gov.au/publications/bulletin/2017/dec/5.html

${ }^{18}$ Götmark, F., Cafaro, P. and J. O'Sullivan. (2018). Aging Human Populations: Good for Us, Good for the Earth. Trends in Ecology \& Evolution. p853.

${ }^{19}$ OECD. (2018). Labour Force Participation Rate. https://data.oecd.org/emp/labour-force-participation-rate.htm and World Bank. (2019). Age-dependency ratio. https://data.worldbank.org/indicator/SP.POP.DPND?view=chart
} 


\section{MACROBUSINESS CONSULTING}

\section{Ageing helps economic growth}

A 2017 study by economists at the Massachusetts Institute of Technology (MIT) found

...that even when we control for initial GDP per capita, initial demographic composition and differential trends by region, there is no evidence of a negative relationship between aging and GDP per capita; on the contrary, the relationship is significantly positive in many specifications. ${ }^{20}$

Their best explanation is that ageing increases investment in automation technologies, and therefore it may have a positive effect on economic growth.

This is consistent with the patterns in Figure 6 showing the per capita economic outcomes of GDP and labour productivity growth since 2000 in the OECD countries. A significant negative correlation is observed. Since population growth rates and population ageing are negatively related, this matches the research showing that ageing increases economic performance.

Population growth and economic performance (2000-17)

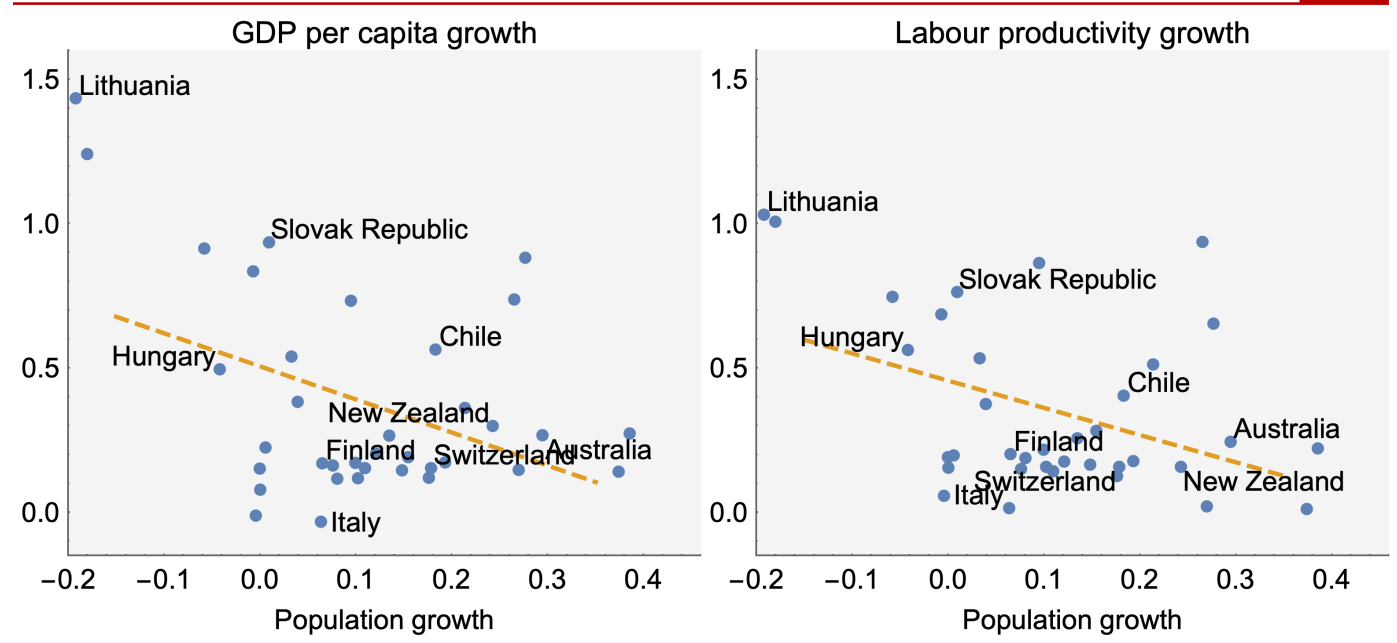

Figure 6: The negative correlation between population growth and economic performance ${ }^{21}$

There is therefore strong evidence against the claim of many commentators ${ }^{22}$ that high population growth leads to better economic performance, and indeed, the economic virtues of an ageing and stable population are clear.

\section{Informal economic contributions}

Lastly, the informal contributions of older Australians to community groups, family support (caring for grandchildren) and generally supporting their friends, neighbours and

\footnotetext{
${ }^{20}$ Acemoglu, D., and Restrepo, P. (2017). Secular stagnation? The effect of aging on economic growth in the age of automation. American Economic Review, 107(5), 174-79. https://economics.mit.edu/files/13126

${ }^{21}$ All data is from OECD.stat and was collected in March 2019. https://stats.oecd.org

22 McDonald, O. (2018). Why cutting Australia's migrant intake would do more harm than good, at least for the next decade The Conversation. https://theconversation.com/why-cutting-australias-migrant-intake-would-do-more-harm-than-good-atleast-for-the-next-decade-108748
} 


\section{MACROBUSINESS CONSULTING}

family, should not be ignored. ${ }^{23}$ Worrying about getting older devalues older people and the significant contributions older people make to our society.

In summary, current ageing trends are a combination of a temporary demographic bulge caused by the echoes of the post-war immigration and baby boom and increasing longevity. The temporary decline will likely see a boost in the bargaining power of workers. Beneath this temporary pattern is a longer-term trend of an upwards shift in the ages at which people participate in the workforce, alongside spending longer in education in early adult life, albeit still working part-time. 


\section{Wrong thing \#2: The high immigration non-solution}

Despite popular thinking to the contrary, immigration policy is also not a feasible countermeasure. It affects population numbers more than the age structure. $^{24}$

Overseas immigration, particularly skilled immigration, is one of the key policy levers that could be used more effectively to manage the impacts of declining workforce population growth and increasing dependency ratios. ${ }^{25}$

One of these quotes must be wrong.

Whether or not you think population ageing provides economic benefits or costs, a separate question is whether high levels of immigration can significantly change the age structure. Can importing more people make people die younger?

It sounds strange to talk about ageing and immigration this way, but since living longer is the primary cause of the ageing population age structure over the long-term, it is also the primary lever for changing the age structure.

While having relatively high rates of immigration and fertility compared with other developed economies, Australia's population will still age dramatically over the coming years. The primary 'culprit' is a virtuous one - Australians are experiencing lower mortality rates and enjoying longer lives ${ }^{26}$

It is certainly the case that low rates of immigration can have some effect on the population age structure, depending on the age distribution of immigrants. However, after multiple inquiries into the topic, the Productivity Commission (PC) concluded that immigration could only fully preserve the current age structure of the population if the rate of immigration was ever-increasing because, after all, immigrants age too.

... stabilisation of the existing age structure would require annual migration rates of 3.1 per cent of the population, resulting in an Australian population of 85 million by 2044-45 and annual net migrant intake at that time of 2.5 million

This is a classic Ponzi (or pyramid) scheme, relying on ever more people entering at the bottom to support the top. Yet, Australia's high immigration policy, which has led to net immigration of 220,000 per year over the past decade, has largely been justified on the basis of solving ageing. ${ }^{27}$

The important question is, therefore, to what degree can immigration policy change the age structure rather than just the population growth rate?

\footnotetext{
${ }^{24}$ PC. (2005). Economic Implications of an Ageing Australia. Productivity Commission Research Report. (p.5) https://www.pc.gov.au/inquiries/completed/ageing/report/ageing.pdf

${ }^{25}$ Victorian Government. (2004). Preparing for Victoria's Future: Challenges and Opportunities in an Ageing Population. (p.55) https://www.pc.gov.au/inquiries/completed/ageing/submissions/victorian_government/sub029.pdf

${ }^{26}$ PC. (2013). An Ageing Australia: Preparing for the future. Productivity Commission Research Report. (p.5) https://www.pc.gov.au/research/completed/ageing-australia/ageing-australia.pdf

${ }^{27}$ ABS. (2018). 3101.0 Australian Demographic Statistics. http://www.abs.gov.au/AUSSTATS/abs@.nsf/cat/3101.0
} 


\section{MACROBUSINESS CONSULTING}

\section{Low immigration reduces ageing, high immigration boosts population}

The two main problems with using immigration to change the age structure are (1) that there are diminishing effects on the age structure at larger immigration rates, and (2) that most of the effect is temporary unless the rate of immigration continues to rise.

....at all points in time, the impact of immigration on ageing is subject to diminishing returns. Each additional 50,000 immigrants has a smaller impact on ageing. Between zero and 50,000 annual net migration, the 50,000 migrants would reduce the proportion of the population aged 65 years and over in the year 2098 by 3.0 percentage points. However, between 200,000 and 250,000 annual net migration, the additional 50,000 migrants would reduce the proportion aged by only 0.5 percentage points. That is, the impact upon ageing of the first 50,000 migrants is six times the impact of the fifth $50,000{ }^{28}$

We can visualise the trade-off between the effect of net overseas immigration on the age structure and the total population by using the models of Peter McDonald and Rebecca Kippen, who studied the efficiency of immigration as a tool to change the age structure.

In Figure 7 we show their results, with the left panel showing the marginal reduction in the age-dependency ratio at the end of the $21^{\text {st }}$ century for each 50,000 increment of immigration, and the right panel showing the effect on population growth at these same immigration levels. While each extra 50,000 immigrants per year will increase the population by 6.7 million by 2098 in these models, the effect on the age structure of each additional 50,000 falls dramatically.

Marginal effects of immigration rate (in 2098)
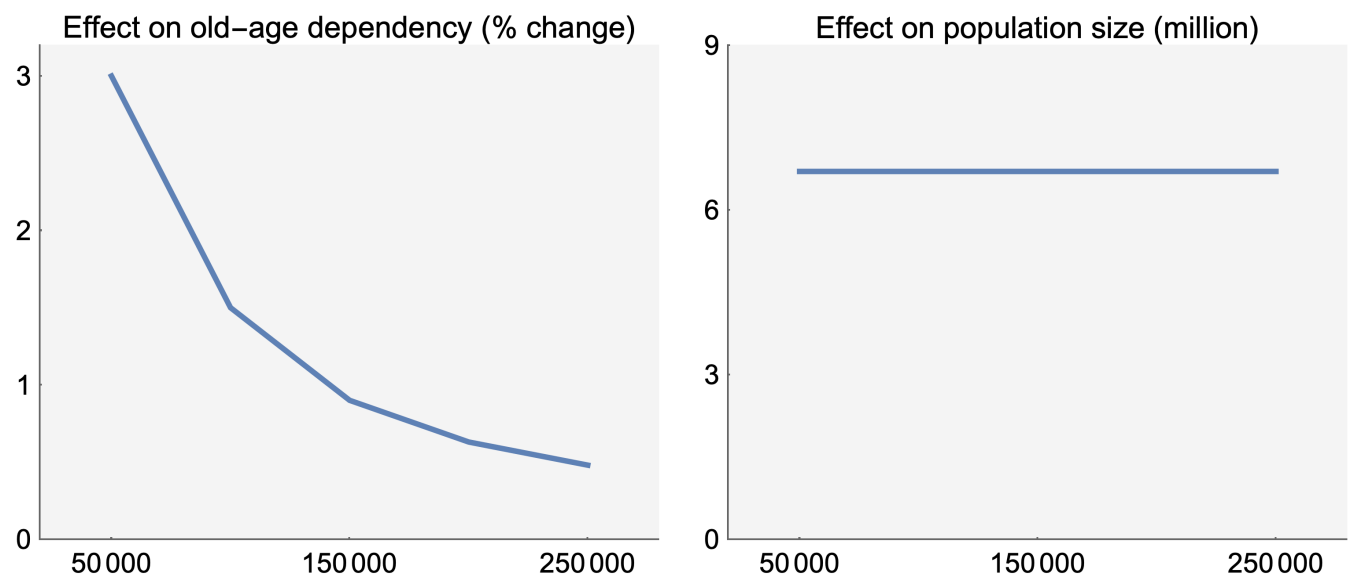

Figure 7: The marginal effect on age structure and growth of each additional 50,000 immigrants ${ }^{29}$

They sensibly concluded that "the largest and demographically most efficient impact of immigration on ageing occurs with the first 50,000 net migrants and that the impact reduces significantly with each additional 50,000 net migrants." 30 This is mostly because

\footnotetext{
${ }^{28}$ McDonald, P. and R. Kippen. (1999). The Impact of Immigration on the Ageing of Australia's Population. Department of Immigration and Multicultural Affairs. https://pdfs.semanticscholar.org/b891/70344b18154431fecb263efd530598ba63fa.pdf $29 \mathrm{lbid}$.

${ }^{30} \mathrm{lbid}$.
} 


\section{MACROBUSINESS CONSULTING}

these low immigration numbers help to stabilise the population size and avoid rapid declines.

To demonstrate how little difference to the overall age structure even extremely high rates of immigration make over the long term, we compare three ABS projection scenarios where the net immigration level are zero, 200,000, and 280,000, per year until 2101. ${ }^{31}$ The projections of the total dependency (youth plus aged) for our low (15 to 65 ) and high (20 to 70$)$ age cut-offs are in Figure 8.

Projected total dependency (low and high age cutoffs)

$\mathrm{MB}$

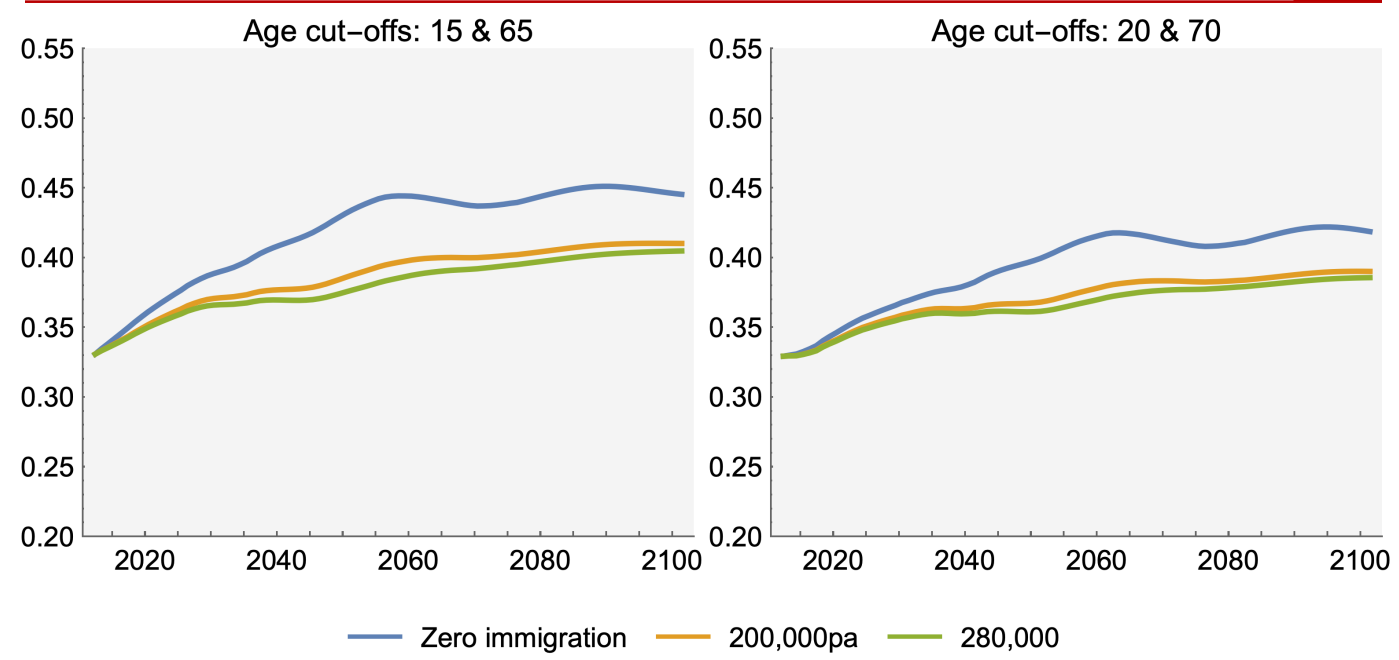

Figure 8: Dependency ratios under two population projections ${ }^{32}$

Both start the with a dependency ratio for the traditional age cut-offs of 15 and 65 years of 0.33 , meaning one third of the population is outside the traditional working age range. By 2100 , the ratio with zero net immigration is 0.45 . With 200,000 net immigration per year that figure is 0.41 , a decline of 3.5 percentage points (ignoring earlier rounding). But adding another 80,000 per year only delivers an additional decline of 0.5 percentage points while increasing the total population by an additional 10 million.

In the zero net migration scenario, the dependency ratio in 2101 is 0.45 . For perspective, in Japan in 2017 the ratio was 0.40 . However, the population in 2101 is 48 million under 200,000 net per annum immigration and only 21 million with zero net migration. The total effect of more than doubling the population this century is to have a dependency ratio 1 percentage point above current day Japan, rather than 4 percentage points above.

In both the young and old workforce age cut-offs, the total dependency ratio still rises substantially for about four decades under all immigration scenarios (as temporary demographic waves pass through). However, in the zero net immigration scenario the ratio peaks this century (twice) before starting to fall. In the high immigration scenarios, the dependency ratio continues climbing even the end of the projection because the additional immigrants themselves age. This highlights the temporary nature (in

\footnotetext{
${ }^{31}$ http://stat.data.abs.gov.au and

http://www.abs.gov.au/AUSSTATS/abs@.nsf/Latestproducts/3222.0Main\%20Features12017\%20(base)\%20-\%202066?op endocument\&tabname $=$ Summary \&prodno $=3222.0$ \&issue $=2017 \% 20$ (base) $\% 20-\% 202066$ \&num $=\&$ view $=$

${ }^{32}$ ABS. (2019). Projected Population, Australia, 2012-2101. Via ABS.stat with medium longevity and fertility assumptions.
} 


\section{MACROBUSINESS CONSULTING}

demographic terms) of the effect of even long periods of high immigration on the age structure.

Such high levels of immigration have relatively small effects on the age structure because most of the effect occurs due to the first 80,000 of net immigration which helps stabilise the population when there is below-replacement fertility. As demographers Peter McDonald and Rebecca Kippen explained:

It is demographic nonsense to believe that immigration can help to keep our population young. No reasonable population policy can keep our population young.

Levels of annual net migration above 80000 become increasingly ineffective and inefficient in the retardation of ageing. Those who wish to argue for a higher level of immigration must base their argument on the benefits of a larger population, not upon the illusory 'younging power' of high immigration. ${ }^{33}$

Using immigration to change the population age structure requires net immigration in the more normal historical range of 50-80,000 per year, rather than high rates of immigration seen recently, of over 200,000 per year, which mostly boosts population size with almost no additional effect on the age structure (assuming the immigration age profile matches recent trends).

\section{What about skills shortages?}

Why are high rates of immigration commonly thought to be desirable if their net effect is simply high population growth? One variation on the ageing-immigration-infrastructure story includes a story not only about a shortage of workers, but a shortage of skills amongst the workforce. Therefore, importing people who have skills is said to contribute to the productivity of the workforce.

Skilled immigration has become the major focus of Australia's permanent migration policy since the 1990 s, making up $62 \%$ of the permanent intake in the past decade compared to $36 \%$ throughout the 1990 s (see Figure 9). Moreover, skilled migration is responsible for almost all the increase in the long-term population growth rate since the early 2000 s.

Alongside, there has been a significant rise in skilled temporary migration, such as via 457 visas (now called Temporary Skills Shortage visas), increasing from around 30,000 per year in the early 2000 s to an average of more than 150,000 since 2012 . Another big group of temporary migrants are students, with the number of temporary student residents up from 170,000 in the early 2000 s to over 400,000 since 2015 . There have been over 600,000 temporary students and workers at any given time in Australia since $2015 .{ }^{34}$

\footnotetext{
${ }^{33}$ McDonald, P. and R. Kippen. (1999). Population Futures for Australia: the Policy Alternatives. Research Paper 5. https://www.aph.gov.au/About_Parliament/Parliamentary_Departments/Parliamentary_Library/pubs/rp/rp9900/2000RP05\# $\underline{8}$

${ }^{34}$ Temporary visa holders in Australia. Data.gov. https://data.gov.au/data/dataset/ab245863-4dea-4661-a334$\underline{71 \mathrm{ee} 15937130}$
} 


\section{MACROBUSINESS CONSULTING}

Annual permanent migrant intake ('000s)
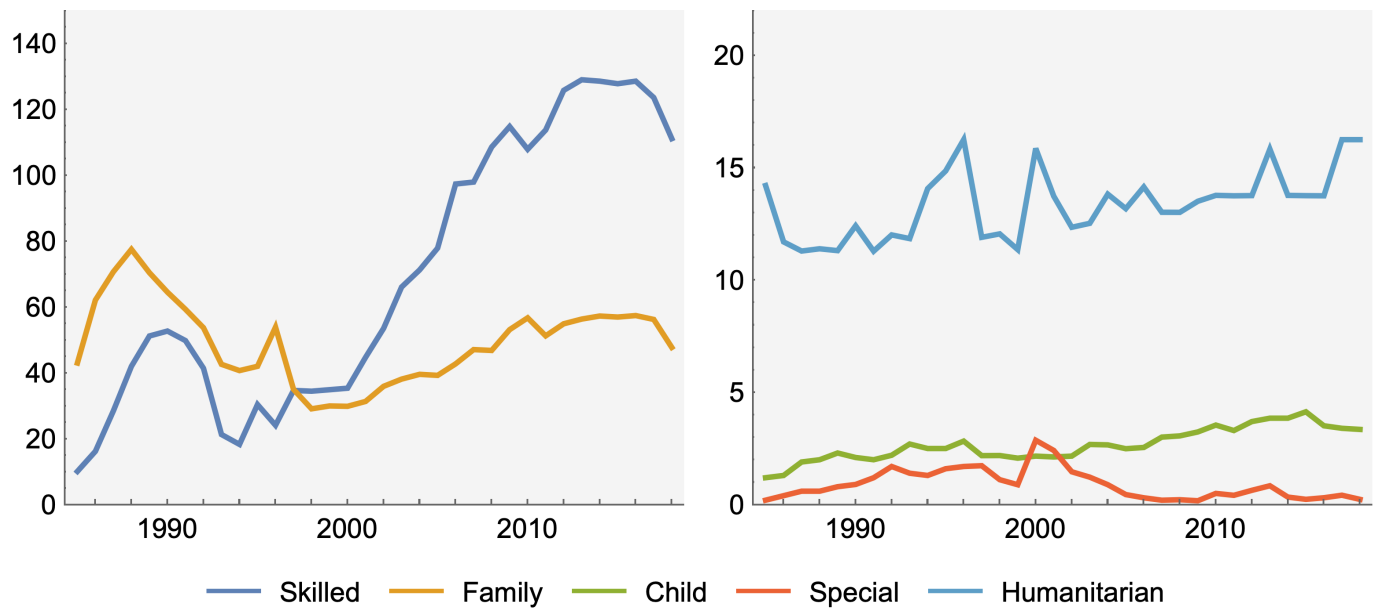

Figure 9: Australia's permanent migration program ${ }^{35}$

While this is a substantial temporary migration program, it is the permanent migration program that is the lever for regulating long-term population growth, as all temporary migrants return to their home country unless they become permanent migrants. ${ }^{36}$

There has been very little discussion of the economic or social objectives of Australia's skilled migration policy (see Box 1). Without a clear rationale for, or objective of, the skilled migration program, it has become mostly a way for business owners to avoiding paying for training, to undercut local worker wages, and to expand their markets.

\section{Box 1: How is it possible for an education exporter to have a skills shortage?}

Australia is widely said to be a world-class "education exporter", where university education is our "third largest export". ${ }^{37}$ It is a puzzle that with such abundant abilities to educate the workforce that so many Australian industries are continually short on skilled workers. After all, Australia having an iron ore shortage seems absurd.

One reason has simply been complacency in the education sector. For example, the number of medical graduates in Australia declined by $20 \%$ as a share of the population between 1984 and $2005 .^{38}$ By the end of this period there was a genuine doctor shortage. But the cause was that medical schools had capped places for many years. After a period of importing many skilled doctors, in 2006 Australian medical schools

\footnotetext{
${ }^{35}$ Phillips, J. and J. Simon-Davis. (2017). Migration to Australia: a quick guide to the statistics. Parliamentary Library. https://www.aph.gov.au/About Parliament/Parliamentary Departments/Parliamentary Library/pubs/rp/rp1617/Quick Guide s/MigrationStatistics

${ }^{36}$ The permanent migration program is the key population policy lever. While $61 \%$ of net overseas migration results from people entering Australia on a temporary visa, Temporary migrants, such as students, either return home at the conclusion of their studies or move on to a permanent visa.

${ }^{37}$ Dodd, T. (2017). Education exports are worth $\$ 28$ billion a year, nearly 20pc more than we thought. AFR. https://www.afr.com/leadership/education-exports-are-worth-28-billion-a-year-nearly-20pc-more-than-we-thought20171005-gyvc8v and Hall, G. and K. Hooper. (2008). Australia's exports of education services. RBA Bulletin. June 2008. https://www.rba.gov.au/publications/bulletin/2008/jun/pdf/bu-0608-2.pdf

${ }^{38}$ OECD. (2019). Medical graduates. https://data.oecd.org/healthres/medical-graduates.htm
} 


\section{MACROBUSINESS CONSULTING}

ratcheted up their intakes significantly, boosting domestic skills again. Between 2006 and 2013 the number of graduation doctors doubled. ${ }^{39}$

Another reason is complacency in large businesses requiring specialist skills. Rather than train people internally they prefer to hire from abroad.

For example, the NSW Government in 2019 explicitly mandated that the winning bidder for its Roads and Maritime Services IT contract - Indian outsourcer Wipro - employ $30 \%$ of its workers from India to keep costs low ${ }^{40}$. Wipro has also been used on IT projects for Sydney Water, employing "hundreds of cut-price Indian IT workers". ${ }^{41}$

It is quite widely accepted that Australia's skilled migration program has failed to be a source of high-skills that are difficult to produce domestically (such as skills in industries that are newly emerging in Australia but where experienced people can be brought in from abroad). The sheer number of occupations that are eligible for skilled visas, shown in Table 1, suggests that the skilled migration program is not targeted at those rare, high value skills that are difficult to acquire domestically. Indeed, there is no requirement that the occupations are actually experiencing skills shortages, meaning that visas can be used by employers who wish to access foreign labour for an ulterior motive, such as to lower wage costs. It is also the case that more than half the migrants in the permanent skilled migration program are 'secondary applicants', usually partners and dependent children, again revealing that the program is not targeted towards highly valuable skills. ${ }^{42}$

Table 1: Number of eligible occupations for skilled visas ${ }^{43}$

\begin{tabular}{l|c|c}
\hline Visa & Subclass & \# of eligible occupations \\
\hline Employer Nomination Scheme & 186 & 216 \\
Regional Sponsored Migration Scheme & 187 & 673 \\
Skilled Independent Visa & 189 & 212 \\
Temporary Graduate Visa & 485 & 212 \\
Skilled Regional (Provisional) Visa & 489 & 504 \\
\hline Skilled Nominated Visa & 190 & 427 \\
Temporary Skill Shortage (TSS) & 482 & 508
\end{tabular}

Adding to the problem is that the salary floor for Temporary Skill Shortage (TSS) visas

\footnotetext{
${ }^{39}$ Health Workforce Australia. (2014). Australia's future health workforce - Doctors. Department of Health. https://www.health.gov.au/internet/main/publishing.nsf/Content/F3F2910B39DF55FDCA257D94007862F9/\$File/AFHW\%2 0-\%20Doctors\%20report.pdf

${ }^{40}$ Hendry, J. (2019). Wipro scores NSW RMS' controversial IT outsourcing deal. itNews. https://www.itnews.com.au/news/wipro-scores-nsw-rms-controversial-it-outsourcing-deal-518674

${ }^{41}$ Clennel, A. (2018). Berejiklian goes overseas for cheap labour. The Australian.

https://www.theaustralian.com.au/news/nation/berejiklian-goes-overseas-for-cheap-labour/newsstory/d20cc183c29eb0afcc4ff5024c297a0f

42 PC. (2016). Migrant Intake into Australia. Productivity Commission Inquiry Report. No. 77. April 2016. https://www.pc.gov.au/inquiries/completed/migrant-intake/report/migrant-intake-report.pdf

${ }^{43}$ Department of Home Affairs. (2019). Skilled migration program. https://immi.homeaffairs.gov.au/what-we-do/skilledmigration-program/recent-changes
} 


\section{MACROBUSINESS CONSULTING}

has been frozen at $\$ 53,900$ since $2013-14$, which is $\$ 32,700$ below the current average full-time Australian salary of $\$ 86,600$ (comprising both skilled and unskilled workers). ${ }^{44}$

Across all skilled visa categories, the median full-time salary 18 months after being granted the visa was $\$ 72,000$ in 2016 , which was below the population average of $\$ 72,900$ (which again comprises both skilled and unskilled workers). ${ }^{45}$

Given the low wages earned, it is difficult to square the idea that the skilled migration program is primarily about bringing high-skilled workers into Australia in areas of genuine shortage. Rather, it is being used to hold down wages, abrogate the need for training, as well as to expand businesses' consumer base.

\section{A shortage and a falling price?}

One of the advantages to a shortage is that the owners of the scarce resource are able to fetch a higher price. However, the wages stagnation ${ }^{46}$ experienced by Australia workers in the past decade suggests that shortages are not common in any part of the labour market.

The Australian Council of Trade Unions (ACTU) has rightly raised many concerns about the conflict between the importation of skills, particularly regarding temporary visas, and the wages for local skills.

"Wright and Constantin (2015) surveyed employers using the 457 visa scheme and found that $86 \%$ state that they have experienced challenges recruiting workers locally. Despite identified recruiting difficulties, the survey found that fewer than 1 in one hundred employers surveyed had addressed 'skill shortages' by raising the salary being offered. Labour 'shortages' should first be addressed through a readjustment in the price of labour - increased wages. An inability to find local workers to work at a specified wage rate, coupled with an unwillingness to offer higher wages, does not necessarily imply a skill shortage - particularly where local workers would be willing and able to work if the wage rate was lifted. This differs from a skill shortage in which there are simply not enough people with a particular skill to meet demand. ${ }^{47}$

We can see in Figure 10 that real wages in Australia have been flat or falling since 2010 despite an economy recovering from the financial crisis and experiencing both a mining and housing boom. Even in professions that make up a high number of the skilled migration intake, such as professional services like accounting, real wages growth is falling. ${ }^{48}$

\footnotetext{
${ }^{44}$ Howe, J. (2018). Is there a wages crisis facing skilled temporary immigrants? In The Wages Crisis in Australia. Ed. Stewart, A, Standford, J, and T. Hardy. https://www.adelaide.edu.au/press/titles/wages-crisis/wages-crisis-ebook.pdf

${ }^{45}$ Home Affairs. (2018). Continuous Survey of Australia's Migrants. Cohort 3 Report-Change in outcomes 2016. https://www.homeaffairs.gov.au/research-and-stats/files/csam-cohort3-report-change-in-outcomes-2016.pdf

${ }^{46}$ Stanford, J. (2018). Wages Crisis Has Obvious Solutions. Centre for Future Work. https://www.futurework.org.au/wages_crisis_has_obvious_solutions

${ }^{47}$ ACTU. (2018). Temporary migration - Changing our system. ACTU Congress 2018. https://www.actu.org.au/media/1034003/temporary-migration.pdf

${ }^{48}$ Leal, H. (2019). Firm-level Insights into Skills Shortages and Wages Growth. RBA Bulletin March 2019. https://www.rba.gov.au/publications/bulletin/2019/mar/firm-level-insights-into-skills-shortages-and-wages-growth.html
} 


\section{MACROBUSINESS CONSULTING}

Real per capita income and wages metrics
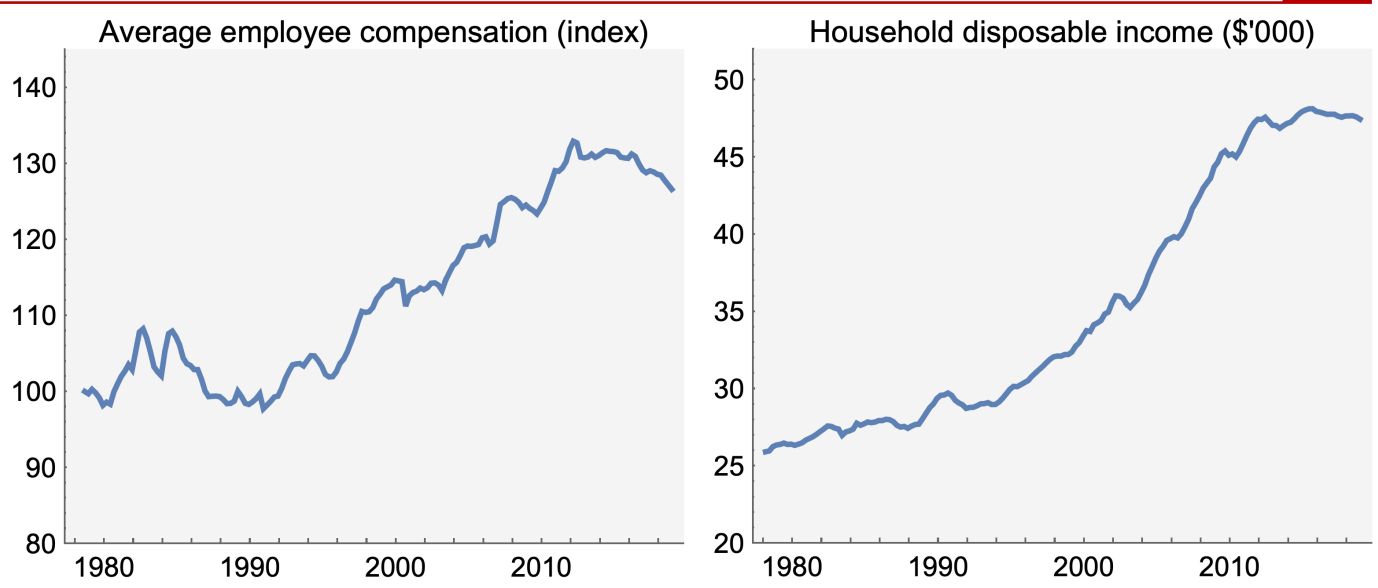

Figure 10: Australian per capita wage metrics are flat or falling ${ }^{49}$

Genuine skills shortages should lead to higher investment in training programs by local businesses, but there is little evidence of this type of response, with a PC report noting that "industry sectors that had raised concerns about skill shortages in recent years had also failed to upskill their workforces or invest in skill capacity renewal"

"The idea that a skills shortage is best solved by importing trained people lacks circumspection. If training were truly a factor limiting productivity of Australian businesses, one would expect to see greater investment by them in training their personnel and providing support for tertiary programs. The opposite is evident - businesses have progressively shed responsibility for staff training, expecting employees to come ready-trained at their own expense. ${ }^{\text {.50 }}$

The ethics of using the immigration program as a way to outsource the costs of education and training while capping local wage growth are questionable by any metric. But there are also ethical concerns regarding the welfare of residents in the origin countries of the genuinely skilled migrants which are rarely discussed and are probably the largest human welfare impact from skilled migration (see Box 2).

\section{Box 2: The ethics of fostering a "brain drain" from developing countries}

Around $80 \%$ of the "skilled" migrants to Australia come from developing nations, which is part of a global pattern of migration from poor to rich countries.

But if this migration removes skills from countries where the gain from those skills in terms of human wellbeing is high, then the costs to residents of origin countries can far exceed any benefits to Australians from a larger pool of skills.

This cost is especially stark when it comes to medical professionals, where the marginal welfare gain to an additional trained doctor or nurse in developing countries is far higher

${ }^{49}$ ABS. (2018). 5206.0 - Australian National Accounts: National Income, Expenditure and Product, Dec 2018. http://www.abs.gov.au/ausstats/abs@.nsf/cat/5206.0 and RBA. (2019). Demand and Income. Table H2. https://www.rba.gov.au/statistics/tables/

${ }^{50}$ O'Sullivan, J. (2014). Submission to the Productivity Commission Inquiry into Infrastructure provision and funding in Australia. https://www.pc.gov.au/ data/assets/pdf file/0004/135517/subdr156-infrastructure.pdf 


\section{MACROBUSINESS CONSULTING}

than it is in developed countries like Australia. ${ }^{51}$ The high costs of training these medical professionals is also usually borne by the origin country. In the medical profession, if not the economics profession, there are significant concerns about the human cost of this "brain drain" style of immigration policy that can stifle development in low-income countries.

An ethical migration system designed to maximise global well-being would aim to educate skilled professionals in the wealthiest countries, while delivering those skills in the poorest countries - the opposite of what occurs in Australia.

Australia's permanent migrant intake is incredibly light on humanitarian places-just 16,250 in 2018 - but heavy on so-called "skilled" migrants, with over 111,000 permanent skilled migrants in 2018 (along with 136,000 temporary skilled resident visa holders in the country as at December 2018). ${ }^{52}$ In terms of the increase in well-being per migrant, humanitarian and low-skilled migration provide much better outcomes.

In all, Australia's immigration system is designed to take skilled human capital from developing nations, stifling their own economic development, while at the same time accepting a comparatively small number of refugees. This is an anti-humanitarian immigration policy.

\section{Who benefits?}

In 2006, the PC completed a major study on the economics of migration and population growth. In it they modelled the impact of a $50 \%$ increase in the level of skilled migration over the 20 years to 2024-25. The modelling found that even skilled migration does not increase the incomes of existing residents. According to the Commission.

...the distribution of these benefits [from skilled migration] varies across the population, with gains mostly accrued to the skilled migrants and capital owners. The incomes of existing resident workers grow more slowly than would otherwise be the case..$^{53}$

The main economic benefit of skilled migration goes to those who migrate and the wealthy owners of capital, while there are many costs felt by others in both their origin and destination countries.

\footnotetext{
${ }^{51}$ Scott, Mark L., et al. "' Brain drain" or ethical recruitment?." Medical Journal of Australia 180.4 (2004): 174. https://www.mja.com.au/system/files/issues/180 04 160204/sco10883 fm.pdf and WHO. (2006). The world health report 2006: working together for health. World Health Organization. https://www.who.int/whr/2006/en/

52 Department of Home Affairs. (2019). BP0014 Temporary Work (Skilled) visa holders pivot table https://data.gov.au/dataset/ds-dga-2515b21d-0dba-4810-afd4-ac8dd92e873e/distribution/dist-dga-35617238-bf65-4654a43e-f50d8e8db0c6/details?q=

${ }^{53}$ Giesecke, James, and G. A. Meagher. (2006). Modelling the economic impacts of migration and population growth. Monash University, Centre of Policy Studies and the Impact Project. https://www.pc.gov.au/inquiries/completed/migrationpopulation/monashmodel/monashmodel.pdf
} 


\title{
Wrong thing \#3: The infrastructure costs of high growth
}

\author{
Don't blame migrants for infrastructure woes, say business leaders ${ }^{54}$ \\ ... Turnbull and Morrison have thus far rebuffed populist incursions, \\ emphasising new investments in infrastructure as a way of easing \\ congestion in the major cities and ensuring services keep up with \\ population growth. ${ }^{55}$
}

Diverting, say, 15,000 permanent skilled immigrants away from each of Sydney and Melbourne in 2019-20 would have no impact on transport congestion. Indeed, it might make it harder to build the required infrastructure, making congestion worse. ${ }^{56}$

The third wrong thing about the standard ageing-immigration-infrastructure story is that the radically higher infrastructure investment needed to maintain per capita levels of access during periods of high immigration are easily accommodated through higher rates of investment.

But this view ignores the many diseconomies of scale that are faced when expanding already built-up cities, which outweighs any economies of scale from more efficient use of capital.

The widely held myth that there are low costs to high growth was echoed by the RBA in $2018 .^{57}$ Only a few gutsy journalists, like Ross Gittins, were willing to push back and acknowledge that high population growth also carries high costs.

Like most economists and business people, Lowe is a lot more conscious of the economic benefits of population growth than the economic costs. As for the social and environmental costs, they're for someone else to worry about. ${ }^{58}$

Many high-profile economists also note the costs to incumbent residents. Paul Krugman noted the "huge negative externalities" from population growth in established areas, such as from additional congestion. Urban economist Ed Glaeser noted that "an influx of new migrants worsens the quality of roads and water for a city's longtime residents" (see Appendix $B$ for details).

${ }^{54}$ SBS. (2018). Don't blame migrants for infrastructure woes, say business leaders. Via AAP.

https://www.sbs.com.au/news/don-t-blame-migrants-for-infrastructure-woes-say-business-leaders

${ }_{55}$ Murphy, K. (2018). Australians growing more concerned over immigration - Guardian Essential poll. The Guardian. https://www.theguardian.com/australia-news/2018/apr/24/australians-growing-more-concerned-over-immigration-guardianessential-poll

${ }^{56}$ McDonald, O. (2018). Why cutting Australia's migrant intake would do more harm than good, at least for the next decade. The Conversation. https://theconversation.com/why-cutting-australias-migrant-intake-would-do-more-harm-than-good-atleast-for-the-next-decade-108748

57 "Philip Lowe said Australia's relatively high immigration rate had created one of the youngest countries among advanced economies, lowered the old-age dependency ratio, increased fertility rates and driven economic growth"

https://www.smh.com.au/politics/federal/australia-is-younger-and-better-off-rba-governor-defends-immigration-rate-20180808p4zw8u.html

${ }^{58}$ Gittins, R. (2018). Fresh blood: Australia is still lucky, thanks to our young migrants. Sydney Morning Herald. https://www.smh.com.au/business/the-economy/fresh-blood-australia-is-still-lucky-thanks-to-our-young-migrants20180810-p4zwob.html 
Some commentators look to previous periods of high population growth as evidence of the low cost of accommodating high population growth with higher infrastructure investment. There are two problems with this view. First, the last period of comparable rapid growth to the 2010s was in the 1950 s and 1960 s, ${ }^{59}$ which also resulted in declining access to infrastructure. New housing subdivisions were created without sealed roads, drainage, or sewers, and public services like hospitals and schools were stretched. Some new suburbs of Melbourne, for example, had no schools and packed their children into church halls and other temporary spaces for lessons. ${ }^{60}$ So difficult was the situation that over that period Commonwealth and State housing programs built nearly 20,000 homes per year for two decades to accommodate the growth. To match that effort in the 2010 s would require a public program of 70,000 additional homes per year (after adjusting for the decline in household size from 3.5 to 2.5 people).

Second, the modern era is qualitatively different when it comes to the infrastructure associated with growth. Cities have fewer frontier spaces to accommodate low-cost expansion, and hence require retrofitting of already-developed areas This comes with high costs. Infrastructure needs in the $21^{\text {st }}$ century are also much higher than they were in the 1950s, with high standards expected across many services, including for example, water, sewer, electricity, fibre, parks and open space, roads, transit, schools, hospitals, and more. ${ }^{61}$

For perspective, Sydney and Melbourne in 2019 have the same population (10 million) as the whole nation had in the late-1950s and have experienced average population growth of $2 \%$ per year for the past decade, booming $22 \%$ overall. ${ }^{62}$ Astonishingly, Melbourne's population increased 11\% in just the four year period between 2014 and 2018 , which is a $2.6 \%$ annual growth on average.

The claim that high population growth is easily accommodated by simply increasing infrastructure investment overlooks three specific issues: (1) diseconomies of scale in infrastructure investment in already built-up areas, (2) the dilution of access and benefits from a fixed natural resource endowment, and (3) the raw scale of infrastructure needs during high population growth.

\section{Diseconomies of scale}

In already built-up cities, new hard infrastructure such as roads, railways, power distribution, water and sewer, stormwater, schools, hospitals, parks and recreational facilities, all face rising costs with increasing densification. Rather than road or rail widenings, tunnels become necessary, for example, meaning that new infrastructure

\footnotetext{
59 This growth was the result of specific post-war policies aimed to increase the population by $2 \%$ per year "to increase the numbers of people able to defend the country in the event of another war". This was achieved by adding $1 \%$ of the population through immigration in addition to the $1 \%$ of natural increase. Spinks, H. (2010). Australia's Migration Program. Parliamentary Library. https://www.aph.gov.au/About_Parliament/Parliamentary_Departments/Parliamentary_Library/pubs/BN/1011/AustMigration

${ }^{60}$ Infrastructure Victoria. (2016). Learning from the Past. A history of infrastructure planning in Victoria. http://www.infrastructurevictoria.com.au/sites/default/files/files/Learning\%20from\%20the\%20past.pdf

${ }^{61}$ For example, even in $196180 \%$ of Brisbane had no sewer. Frost, Lionel, et al. (2016). "Water, history and the Australian city: Urbanism, suburbanism and watering a dry continent, 1788-2015." https://watersensitivecities.org.au/wpcontent/uploads/2016/12/A2.1_2_2016_R5-19-12-2016-V2.pdf

One of Gough Whitlam's achievements was to "help resolve the many problems of the swollen, new suburbs of the capital cities", which included getting the 45 percent of homes without sewerage connected to a public system.

62 ABS. (2018). 3218.0 - Regional Population Growth, Australia, 2017-18. http://www.abs.gov.au/AUSSTATS/abs@.nsf/mf/3218.0
} 


\section{MACROBUSINESS CONSULTING}

expansions are more costly than existing infrastructure investments were. Rather than a new dam on the next valley, additional water supply must come from expensive desalination.

These costs are often overlooked because the incremental infrastructure needs of infill development can appear quite low. Many studies suggest that incremental additions of homes and people within established areas are associated with lower infrastructure costs because of economies of scale from using existing infrastructure. ${ }^{63}$ But this depends "on the capacity of existing infrastructure to support additional people." ${ }^{\prime 4}$ For very small changes to population this is a reasonable assumption. For the $20 \%$-plus growth per decade in Sydney and Melbourne this assumption does not hold.

The PC has noted these problems.

Delivering infrastructure for infill development presents governments with new challenges that our planning, funding, and governance arrangements were not designed to address. For example, construction of new infrastructure is often more expensive, due to the need to tunnel under existing structures or purchase land at higher costs. The small scale, incremental nature of growth in established areas can also lead to an overreliance on existing infrastructure, which can result in congestion and overcrowding. ${ }^{65}$

To expand the water supply example, a small incremental population increase might not require any new water sources. However, a large change means that new sources are required, and since low-cost locations for dams have already been used, only high-cost options remain, like desalination, recycling, and raising dam walls. The cost of desalinated water is more than four times the cost of dam water (see Figure 11). This pattern of increasing costs-a diseconomy of scale in water supply-has led Infrastructure Australia to forecast that household water bills will increase by $40 \%$ per decade for the foreseeable future (in real terms). ${ }^{6}$

\footnotetext{
${ }^{63}$ For example, see Giannakodakis, G. (2013). Urban infill vs Greenfield Development. A review of economic benefits and costs for Adelaide. InfraPlan discussion paper for Department of Planning, Transport and Infrastructure. https://dpti.sa.gov.au/ data/assets/pdf file/0009/123210/InfraPlan Report Infill versus Greenfield Development Adelai de_-Final_report.pdf

${ }^{64}$ SGS. (2016). Comparative costs of urban development: a literature review. Final report for Infrastructure Victoria. SGS Economics and Planning. https://s3.ap-southeast-2.amazonaws.com/hdp.au.prod.app.iv30year.files/1714/7546/2887/SGS_Economics_and_Planning_-

_Comparative_costs_of_infrastructure_across_different_development_settings.PDF

${ }^{65}$ Infrastructure Australia. (2018). Planning Liveable Cities. A place-based approach to sequencing infrastructure and growth. (p4). https://infrastructureaustralia.gov.au/policypublications/publications/files/IFA 225232 Planning Liveable Cities Report\%202018 FA Web LR.pdf

${ }^{66}$ Infrastructure Australia. (2017). Reforming urban water. A national pathway for change. https://infrastructureaustralia.gov.au/policy-publications/publications/files/Reforming Urban Water Web version.pdf
} 


\section{MACROBUSINESS CONSULTING}

Victorian water supply costs $(\$ / \mathrm{kL})$

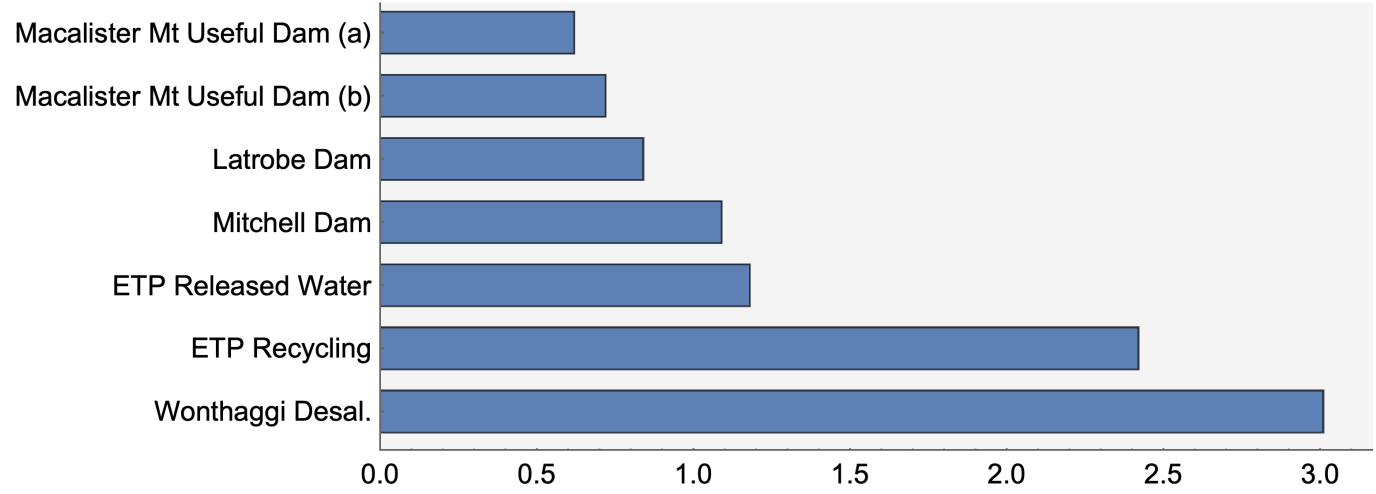

Figure 11: Rising costs of new Victorian water supply sources ${ }^{67}$

Transport infrastructure is another well-known example.

Growing populations will place pressure on already strained transport systems. The overall freight task in Australia is projected to increase by 26 per cent within a decade from 2015, and 86 per cent by 2031, much of which will comprise deliveries utilising roads within capital cities.

Yet available choices for new investments are constrained by the increasingly limited availability of unutilised land. Costs of new transport structures have risen accordingly, with new developments (for example WestConnex) requiring land reclamation, costly compensation arrangements, or otherwise more expensive alternatives (such as tunnels). ${ }^{68}$

In Figure 12 we see the huge cost of expanding the road network through established urban areas with tunnelling compared to the cost of other greenfield road expansions. The WestConnex project in Sydney will reportedly cost $\$ 17$ billion for 33 kilometres ( $\$ 515$ million per kilometre) while Melbourne's West Gate Tunnel is expected to cost $\$ 6.7$ billion for 5 kilometres of highway ( $\$ 1.34$ billion per kilometre). In contrast, surface highways through undeveloped land are far cheaper. The 155 kilometres Woolgoolga to Ballina highway upgrade, for example, costs $\$ 4.9$ billion, or just $\$ 31$ million per kilometre (approximately 11 times less than WestConnex, and 29 times less than the West Gate Tunnel, on a "per lane" basis). ${ }^{69}$

\footnotetext{
${ }^{67}$ Moran. A. (2008). Water supply options for Melbourne. An examination of costs and availabilities of new water supply sources for Melbourne and other urban areas in Victoria. Submission to the Environment and Natural Resources Committee Inquiry into Melbourne's Water Supply. IPA.

https://www.parliament.vic.gov.au/images/stories/committees/enrc/future_water_supply/Submissions_57_110/098_Institute _of_Public_Affairs.pdf

${ }^{68}$ PC. (2017). Shifting the Dial: 5-year productivity review. Productivity Commission Inquiry Report. https://www.pc.gov.au/inquiries/completed/productivity-review/report/4-towns-cities

${ }^{69}$ NSW Government. (2018). Pacific Highway Upgrade. Woolgoolga to Ballina. https://www.pacifichighway.nsw.gov.au/project-sections/coffs-harbour-to-ballina/woolgoolga-to-ballina
} 


\section{MACROBUSINESS CONSULTING}

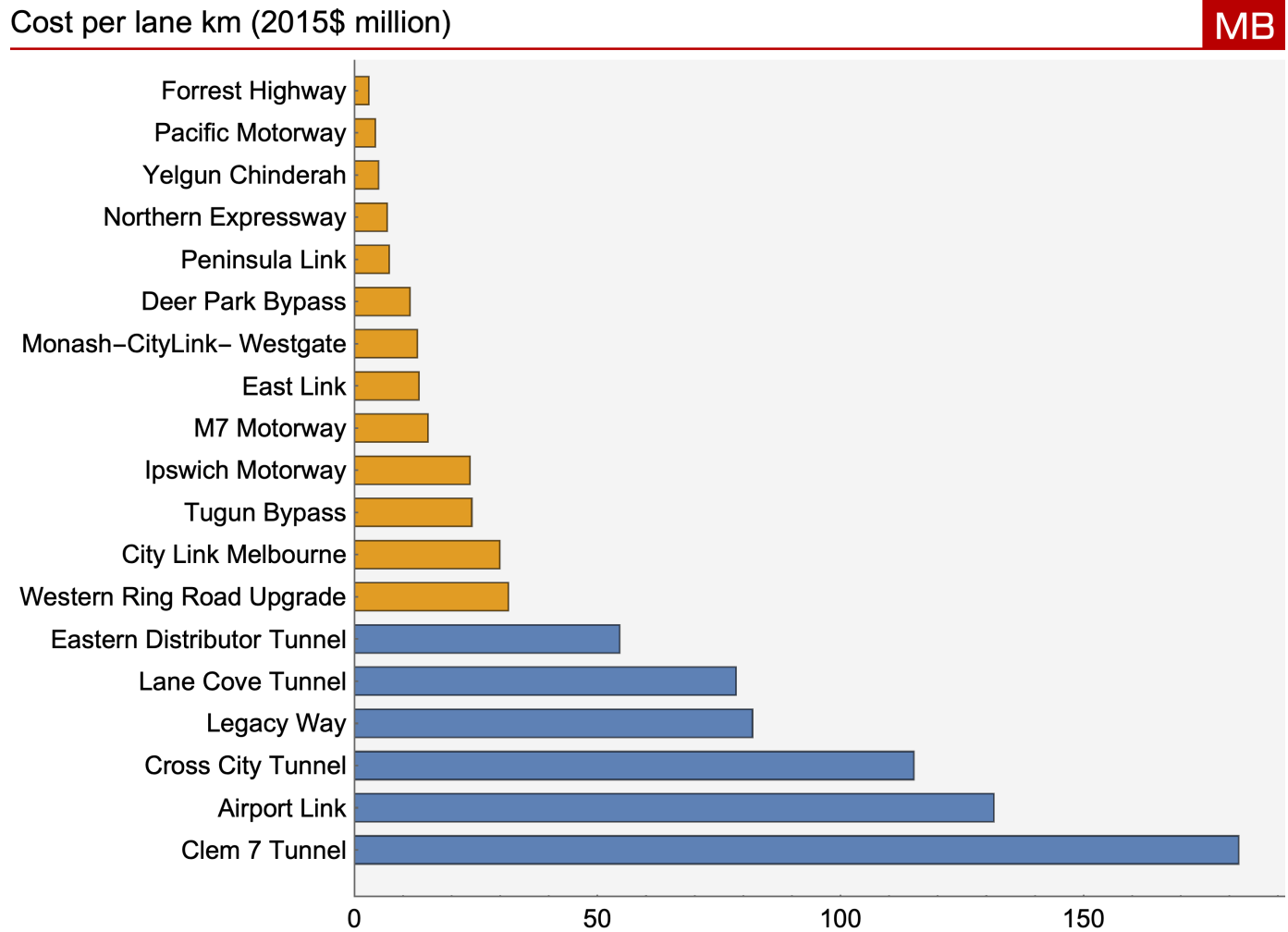

Figure 12: The high cost of infill road expansion ${ }^{70}$

\section{Diluting our environmental endowments}

Australia's environmental endowment of resources is fixed. The number of beaches, the yield of fisheries, the stock of minerals, water, and fertile agricultural land cannot grow with the population.

As an economy heavily reliant on its use of depletable mineral resources, this dilution necessarily means fewer benefits per capita from the use of these resources. Although there is scope to distribute more of the benefits from extracting our endowment of finite resources, whatever system is in place will bring more benefits per capita with fewer people.

For example, the $\$ 11$ billion of royalties paid by the mining industry in 2016-17 was $\$ 448$ per capita. If population growth since 2006 had been at more typical historical norms of $1 \%$ instead of $2 \%$, this would be $8.3 \%$ higher at $\$ 485$ each.

Because the natural environmental endowment cannot be duplicated, many tourist hotspots are becoming 'loved to death', congested and their amenity eroded through overuse. ${ }^{71}$ Australia today has half as many beaches per person as it had in 1970. There is no escaping that this leads to more crowding, reducing the value to each visitor.

\footnotetext{
${ }^{70}$ Data from Elaurant, S., \& Louise, J. (2015). Politics, finance and transport-megaprojects in Australia. Proceedings of the Royal Society of Queensland, The, 120, 31.

${ }^{71}$ Milano, C. et. al. (2018). Overtourism: a growing global problem. The Conversation. https://theconversation.com/overtourism-a-growing-global-problem-100029
} 


\section{MACROBUSINESS CONSULTING}

The first national report on the State of the Environment in 1996 stated that Australians are not living sustainably, and that all of the country's environmental problems are more or less proportional to the number of residents, as well as the material standard in which we live:

The problems are the cumulative consequences of population growth and distribution, lifestyles, technologies and demands on natural resources over the last 200 years and more. ${ }^{72}$

The latest State of the Environment report from 2016 also found that population growth is a key driver of Australia's environmental problems:

The key contemporary drivers of Australian environmental change considered in state of the environment (SoE) 2016 are population (demographic change) and economic activity.

Continued growth in Australia's population and economy, including to meet demand for exports, is likely to increase pressures on the Australian environment...

The concentration of Australia's population near the coast, mostly in urban areas, creates substantial pressure on coastal ecosystems and environments in the east, south-east and south-west of the country... ${ }^{73}$

Since the first State of the Environment report was delivered in 1996, Australia's population has ballooned from 18.3 million to more than 25 million, with projections of reaching 43 million by 2066 without changes to population policy.

There would appear to be few better policy solutions to help protect Australia's environment than reducing long-term population growth.

\section{The scale of necessary infrastructure investment is immense}

High population growth is costly for incumbent residents because of the need for 'capital widening' to accommodate new residents with the existing levels of infrastructure access by merely duplicating and expanding infrastructure. Building more road, homes, parks or hospitals so that each household has the same stock per capita is duplication that provides no net gains per capita.

Capital deepening-increasing the stock of infrastructure per person-is what causes productivity growth and happens when the stock of capital is expanded on a per capita basis. Thus, there is an inherent trade-off between productivity growth from capital deepening and the necessary capital widening needed to accommodate high population growth.

This is illustrated in Table 2. We show how much additional infrastructure investment is required to ensure a constant level of infrastructure per capita compared with the situation of no population growth. In economic terms, how much more capital widening is needed because of population growth compared to the no population growth scenario

\footnotetext{
72 State of the Environment Advisory Council. (1996). Australia State of the Environment. A report for the Commonwealth Minister for the Environment. https://soe.environment.gov.au/sites/default/files/1996-soe.pdf?v=1487244614

${ }^{73}$ State of the Environment Advisory Council. (2016). Australia State of the Environment. A report for the Commonwealth Minister for the Environment. https://soe.environment.gov.au/theme/drivers/key-findings?year=96\#key-finding-72491
} 


\section{MACROBUSINESS CONSULTING}

where only maintenance and replacement for ageing infrastructure is needed? We look at the typical range of infrastructure design lives of 25 to 50 years. ${ }^{74}$

In a scenario where infrastructure has a short lifetime of 25 years, $1 \%$ population growth requires a $25 \%$ increase in infrastructure investment to ensure the stock of capital per capita is maintained. A $2 \%$ population growth rate means a $50 \%$ increase. At the other end of the scale with long-lived public infrastructure, a $1 \%$ population growth rate needs $50 \%$ more infrastructure investment per year, while a $2 \%$ growth rate needs a double infrastructure investment.

The difference between no population growth and a $2 \%$ population growth is not $2 \%$ more investment each year, but 50-100\% more.

Table 2: Increase in infrastructure investment needed each year for capital widening

\begin{tabular}{r|cc} 
& \multicolumn{2}{|c}{ Infrastructure life (years) } \\
Population growth (\%) & $\mathbf{2 5}$ & $\mathbf{5 0}$ \\
\hline $\mathbf{0}$ & - & - \\
$\mathbf{1}$ & $25 \%$ & $50 \%$ \\
$\mathbf{2}$ & $50 \%$ & $100 \%$
\end{tabular}

In the 1990s, $7.2 \%$ of the workforce worked in construction on average. ${ }^{75}$ Since 2010 it has averaged just under $9 \%$, a $25 \%$ increase, showing that the capital-widening needed to accommodate high population growth requires a significant share of the workforce to not do other things, and instead participate in capital-widening efforts. Despite this significant increase in the construction workforce, it is widely acknowledged that investment has not been sufficient to ensure capital widening, let alone capital deepening, with Infrastructure Australia noting "our largest cities are 'playing catch up' in delivering infrastructure to support population growth"76

We can get a picture of the scale of this by referring to the estimates in Table 3 of the cost of expanding the capital stock for some basic services. We can somewhat ignore for the moment the additional running costs of nurses, doctors, teacher, police, and carers, as they will be drawn from a larger population pool. Back-of-the-envelope calculations suggest a capital widening cost of $\$ 7,142$ per extra person per year for just these services. At 1\% population growth that is $\$ 1.7$ billion, and at $2 \%$ it is $\$ 3.5$ billion per year.

Table 3: Indicative costs per person of growth each year for capital widening ${ }^{77}$

\begin{tabular}{r|cc} 
Service & Cost/person/year & Cost of 1\% growth \\
\hline Hospitals & $\$ 12,000$ & $\$ 3,000 \mathrm{~m}$ \\
Childcare and schools & $\$ 1,814$ & $\$ 454 \mathrm{~m}$
\end{tabular}

\footnotetext{
${ }^{74}$ Evidence suggests public infrastructure typically has a lifespan of 20 to 40 years, though with substantial variation. (see Summary result of second Eurostat questionnaire on CFC on public infrastructure, DOC.CFC 15, Eurostat, 2003 and Marland, GR., and Weinberg., AM. (1988). Longevity of infrastructure. National Academy Press, Washington, DC)

${ }^{75}$ ABS. (2018). 6291.0.55.003 - Labour Force, Australia, Detailed, Quarterly, Nov 2018. https://www.abs.gov.au/AUSSTATS/abs@.nsf/Lookup/6291.0.55.003Main+Features1Nov\%202018?OpenDocument

${ }^{76}$ Infrastructure Australia. (2018). Planning Liveable Cities. A place-based approach to sequencing infrastructure and growth. (p4). https://infrastructureaustralia.gov.au/policypublications/publications/files/IFA 225232 Planning Liveable Cities Report\%202018 FA Web LR.pdf

77 Refer to Appendix C for calculation method.
} 


\begin{tabular}{r|cc} 
Aged care & $\$ 1,768$ & $\$ 442 \mathrm{~m}$ \\
Public transport (incl. operations) & $\$ 9,200$ & $\$ 2,300 \mathrm{~m}$
\end{tabular}

Add in water, parks, and other essential services, and the cost of high population growth become very large very quickly.

\section{Opportunity costs of political capital}

Lastly, the additional infrastructure costs of population growth mean that not only are resources diverted from other potential uses that can deepen capital, but political capital is diverted to addressing concerns about rapid growth and the local effects of that growth.

This political distraction means that social programs to help improve social circumstances with support for issues from mental health, drug, homelessness, to indigenous disadvantage, take a backseat (particularly if re-election requires attention to planning and congestion issues arising from rapid growth).

Additionally, political attention becomes devoted to overcoming the tension arising because the high costs of service and infrastructure provision are a state and local council matter, while tax revenues from additional people go to the federal government. These funding challenges and government budgeting tensions mean many new infrastructure systems are often user-funded, adding to costs in the form of 'private taxes' (user charges) for workers, many of which are lower income and rely heavily on public services to maintain their quality of life. 


\section{Policy recommendations}

If ageing is not an economic problem, nor immigration a useful countermeasure to ageing, and if high immigration is costly to residents, the policy direction for maximising the welfare of existing residents looks quite different to the current conventional wisdom.

\section{Reframe ageing as an economic success}

Foster a culture that celebrates our long and healthy lifetimes, ageing needs to be recast as the economic success that it is rather than being labelled an economic problem. Older Australians are making more of a positive contribution than ever, and the experience of ageing globally is one of sustained participation and high economic growth.

\section{Reframe immigration as an environmental, social and economic choice}

There is no right or wrong population or immigration level. However, the choice of population and immigration policy is one in which all Australian's have a stake. There are environmental considerations regarding the sharing of limited natural endowments, social considerations regarding the density and style of our cities and towns, ethical consideration about the distribution of skills globally, and economic considerations both in terms of the distribution of costs and benefits. Naïve stories about high immigration being an economic necessity due to ageing need to be corrected.

\section{Lower population growth by reducing skilled migration}

The simplest way to reduce population growth is to reduce the size of the permanent skilled migration program back to historical norms of $30-40,000$. This can be achieved by updating the salary floor for temporary skilled visas to $150 \%$ of the average full-time salary of $\$ 86,600$, or $\$ 129,900$, while also applying this salary floor as a condition of permanent skilled visas. The salary floor can be periodically indexed to average full-time salary (every two or three years).

Using a salary floor as the mechanism to establish the desirability or demand for skills eliminates the need for market testing, which is easily circumvented. It would also reserve Australia's skilled immigration program for highly paid, highly skilled migrants in select areas of genuine need. Appendix D elaborates this recommendation.

The net effect would be to decrease the total permanent immigration program to around 80-90,000 per year, and after permanent departures are taken into account, would stabilise permanent net immigration in the desirable $50-80,000$ range.

\section{Planning for infrastructure}

To ensure that the true costs of maintaining quality infrastructure are understood, state and local governments should be required to include forecasts of infrastructure needs based on the development capacity of the town planning instruments, and embed in these instruments a requirement for the infrastructure services to be delivered at a rate that matches the rate of development. Commitments to health, education, transit, and police services should be included in addition to traditional upgrades and investment in local council services such as parks, roads, water supply and stormwater, and sewers. Exactly how these planned infrastructure commitments are determined should involve local community input. 


\section{Appendix A: The growth lobby behind a 'Big Australia'}

In 2006, Dr Katharine Betts identified "a growth lobby concentrated among interests based in housing, land development and construction" as being behind the forces advocating mass immigration and a 'Big Australia'. ${ }^{78}$ Large retailers, the banking sector, and toll road providers can also be considered part of the 'growth lobby' since they too benefit directly from a bigger Australia.

This 'growth lobby', according to Dr Betts, comprises key players that are rich and powerful, including the CEOs of Australia's largest corporations. ${ }^{79}$ They are backed by an array of erroneously named 'think tanks' and not-for-profit lobbyists that support the mass immigration program, while largely ignoring the cost burden on ordinary residents.

Membership of the 'growth lobby' is pervasive and includes wealthy and powerful individuals like billionaire Meriton Apartments founder Harry Triguboff and Billionaire retailer Gerry Harvey, both of whom have frequently called for Australia's immigration program to be increased, presumably to expand their customer base.

Property industry groups like the Property Council of Australia, the Housing Industry Association, Master Builders Australia, and the Urban Taskforce also frequently lobby for Australia's mass immigration policy to be maintained or expanded, as do business lobby groups like the Australian Industry Group, the Australian Chamber of Commerce and Industry, and the Business Council of Australia.

Various not-for-profit organisations backed by big business also advocate for mass immigration and a 'Big Australia'. These include the Migration Council of Australia (chaired by Australian Industry Group CEO Innes Willox), the Scanlon Foundation (founded by real estate developer Peter Scanlon), the Lowy Foundation (founded by billionaire Westfield founder Frank Lowy), and the Committee for Economic Development of Australia (whose membership is dominated by "Australia's leading businesses").

The common thread behind Australia's 'growth lobby' is that its members privatise the gains that arise from mass immigration via the expansion of the domestic market and the reduction in wages, while the costs are socialised among the broader Australian community.

\footnotetext{
${ }^{78}$ Betts, K., and M. Gilding. (2006). The growth lobby and Australia's immigration policy. People and Place, 14(4), 40. http://tapri.org.au/wp-content/uploads/2016/02/v14n4 6bettsgilding.pdf

${ }^{79}$ Yeates, C. et. al. (2019). 'Extremely important': CEOs back immigration as cuts to intake loom. Canberra Times. https://www.canberratimes.com.au/business/the-economy/extremely-important-ceos-back-immigration-as-cuts-to-intakeloom-20190310-p5131r.html
} 


\section{Appendix B: Economists on high growth infrastructure costs}

Nobel Prize winning economic Paul Krugman explained that the population growth from a new Amazon headquarters in New York would not be unambiguously good. ${ }^{80}$

So Amazon isn't coming to New York. Is this a good thing or a bad thing? Let me tell you a secret: NOBODY KNOWS 1/

The crude argument for the deal - Amazon would bring jobs! - is basically stupid. New York in general and Queens in particular have very low unemployment by historical standards, so any job creation would mainly involve bringing in more people 2/

These additional people would add to the city economy, but also receive salaries. So where's the net gain? Well, they would pay taxes - and NYC has high marginal tax rates, so that's a fairly big deal 3/

They would also expand the (already huge) pool of skilled labor and strengthen the (already huge) information spillovers, so the positive externalities of New York's size would grow. But ... 4/

New York also has huge negative externalities. Traffic congestion costs the average resident of Queens $\$ 1500$ a year 5/

I haven't found a standard estimate of the social costs imposed by adding another commuter to NY streets, but they have to be in the thousands, probably tens of thousands of dollars 6/

There's some social cost to adding more high-paid workers to a housing market that already prices out middle- and lower-income workers. The right answer is less NIMBYism and more housing, but that will take time 7/

So put it all together and the best bet is that Amazon would have a significant effect on the welfare of NY residents -- but whether it's significantly positive or significantly negative is really anyone's guess 8/

The effect of population growth in established cities according to Edward Glaeser is:

The vast flow of migrants to cities certainly stresses urban infrastructure; that's one of the familiar arguments against allowing the growth of megacities. But while an influx of new migrants worsens the quality of roads and water for a city's longtime residents, the new arrivals go from having virtually no infrastructure to enjoying all the advantages of that come from access to decent transport and utilities. It is wrong to keep the quality of urban infrastructure high by preventing people from enjoying that infrastructure. It's more ethical-and more economically beneficial for the country as a whole-to invest more in urban infrastructure so more people can benefit from it. ${ }^{81}$

\footnotetext{
${ }^{80}$ Krugman. P. (2019). Twitter thread. https://twitter.com/paulkrugman/status/1096875749699575808

${ }^{81}$ Glaeser, E. (2011). Triumph of the City. Pan. p75.
} 


\section{Appendix C: Indicative costs of services (capital-widening)}

\section{Hospitals}

There are 4.0 hospital beds per 1,000 people in Australia, below the OECD average of 4.8. ${ }^{82}$ Each new bed costs $\$ 3$ million on average if we use the data in Table 4. Therefore, to maintain the same ratio of beds per capita means spending $\$ 12,000$ per new person.

Table 4: Capital cost of recently-built Australian hospitals (from various online news sources)

\begin{tabular}{r|ccc} 
Recently built hospitals & \$millions & beds & \$m per bed \\
\hline Gold Coast University Hospital & 1890 & 750 & 2.5 \\
Queensland Children's Hospital & 1513 & 359 & 4.2 \\
Sunshine Coast University & & & \\
Hospital & 2030 & 738 & 2.8 \\
Royal Adelaide Hospital & 2440 & 800 & 3.1 \\
Perth Children's Hospital & 1200 & 298 & 4.0 \\
Fiona Stanley Hospital & 2000 & 783 & 2.6 \\
Joondalup mental health facility & 154 & 75 & 2.1 \\
Perth Children's Hospital & 1200 & 298 & 4.4 \\
Average & & & $\mathbf{3 . 0}$
\end{tabular}

Childcare, schools, aged care, public transport

Borrowing from other research commissioned by Melbourne's outer suburban growth areas, ${ }^{83}$ we can reverse out per capita costs of capital-widening as follows.

Childcare: $\$ 98.50$ per person

Primary School: $\$ 952$ per person

Secondary school: $\$ 763$ per person

Total: $\$ 1,814$ per new person.

Aged care: $\$ 1,768$ per new person

Public transport: $\$ 9,200$ per new person

\footnotetext{
${ }^{82}$ Australian Institute of Health and Welfare. (2018). Hospital resources 2015-16: Australian hospital statistics. https://www.aihw.gov.au/reports/hospitals/hospital-resources-ahs-2015-16/contents/summary

${ }^{83}$ Dowling, J. (2013). \$10b price tag to service city's growth areas. The Age.

https://www.theage.com.au/national/victoria/10b-price-tag-to-service-citys-growth-areas-20130212-2eb62.html
} 


\section{Appendix D: How to fairly lower the immigration intake}

Various commentators have questioned the practicality of cutting Australia's immigration intake, claiming that it would unduly penalise families and employers. Fairfax's chief political correspondent, David Crowe, captured this argument with the following in July 2018:

What few politicians can admit is just how hard it is to move the door and limit the migration intake...

Consider three options that would have to be on the table for any further cut to Australia's permanent migration intake...

Option one is to divide families. The family stream takes about 47,000 people, most of them spouses who come with their Australian partners. Are some of them to be turned away?...

Option two is to punish employers. The skilled stream takes about 111,000 people, a combination of workers sponsored by employers and those who come independently after proving they can fill a labour shortage. How low can this go?...

Option three is to turn away refugees. The humanitarian intake is 16,250and the only area in the population debate where political parties compete to go higher...84

The truth is, reducing Australia's permanent migrant program back near turn-of-thecentury levels needn't be difficult.

\section{Reduce the intake of both permanent and temporary skilled migrants}

At the turn-of-the-century, Australia's permanent skilled intake was 35,000. From 201920 it will be 108,682 following the Coalition Government's changes in the 2019 Federal Budget.

The common claim by the business lobby that Australia is suffering from "skills shortages" is false. Australia's skilled migrant program has been widely gamed, attracting migrants to areas already heavily oversupplied with workers (e.g. accounting, engineering and IT). Most migrants have also been employed at levels well below their claimed skills set ${ }^{85}$, and 'skilled' migrants generally have experienced significantly higher unemployment and underemployment than the Australian born population ${ }^{86}$, alongside lower salaries ${ }^{87}$.

\footnotetext{
${ }^{84}$ Crowe, D. (2018). Is the door too open or too closed when it comes to population? Sydney Morning Herald. 20 July 2018. https://www.smh.com.au/national/is-the-door-too-open-or-too-closed-when-it-comes-to-population-20180720-p4zsmi.html

${ }^{85}$ Birrell, B. (2018). Australia's skilled migration program: scarce skills not required. The Australian Population Research Institute. http://tapri.org.au/wp-content/uploads/2016/04/Final-March-8-Australias-skilled-migration-program.pdf

${ }^{86}$ ABS. (2017). 6250.0 - Characteristics of Recent Migrants, Australia, November 2016. http://www.abs.gov.au/ausstats/abs@.nsf/mf/6250.0

${ }^{87}$ Home Affairs. (2018). Continuous Survey of Australia's Migrants. Cohort 3 Report—Change in outcomes 2016. https://www.homeaffairs.gov.au/research-and-stats/files/csam-cohort3-report-change-in-outcomes-2016.pdf
} 
The heavy weighting towards "skilled" migrants also means that Australia's immigration system is built around robbing developing nations of their skilled human resources, stifling their economic development.

Therefore, the "skilled" program should be phased back to 35,000 over, say, three years and be reserved only for truly world-class leaders in their field that Australia cannot foster internally.

To ensure that the skilled intake is used for genuine skills shortages, a wage floor should be set at $150 \%$ of the average full-time salary, which is currently $\$ 86,600$ (and which includes unskilled workers).

A pay floor of $\$ 129,900$ (indexed to the average full-time salary) would eliminate the need for market testing, which is easily circumvented. It would also reserve Australia's skilled intake for highly paid, highly skilled migrants in select areas of genuine need.

This same pay floor should also extend to temporary skilled migration, thereby, replacing the appallingly low pay floor of $\$ 53,900$ (non-indexed). By maintaining such a low pay floor for temporary 'skilled' foreign workers, the government has ensured the system has been overused and abused by employers, thereby undermining the pay and working conditions of local workers. This needs to stop.

Under the above proposed reforms, employers would no longer be allowed to simply 'grab a migrant' to fill ordinary positions in the labour market cheaply. Instead, they would have to lift wages to attract workers (thus countering Australia's problem of anaemic wages growth), as well as commit to training local workers.

Cutting the permanent skilled intake in this way would also reduce the flow of temporary migrants over and above raising the pay floor for skilled workers. This is because many migrants first come to Australia on temporary visas (e.g. as international students or TSS visas) with the hope of transitioning to a skilled permanent visa later.

Therefore, if the carrot of permanent residency is restricted by slashing the 'skilled' intake, then it would also reduce the flow of temporary migrants, since the two areas are intrinsically linked.

\section{Possibly reduce the intake of parental visas under the family stream}

Within the 48,000 strong Family Stream of permanent migrants in 2017-18 were 7,400 parental visas, issued to parents of Australian residents. In its 2016 Migrant Intake into Australia Report, the Productivity Commission (PC) noted that these parental visas cost Australian taxpayers between $\$ 2.6$ and $\$ 3.2$ billion in present value terms, with the cost likely to rise over time as numbers increase. The PC also concluded that "the case for retaining parent visas in their current form is weak".

The contributory visa charge of just under $\$ 50000$ meets only a fraction of the fiscal costs for the annual intake of roughly 7200 contributory parents. And an additional 1500 parents make a minimal contribution. Overall, the cumulated lifetime fiscal costs (in net present value terms) of a parent visa holder in 2015-16 is estimated to be between $\$ 335000$ and $\$ 410000$ per adult, which ultimately must be met by the Australian community. On this basis, the net liability to the Australian community of providing assistance to these 8700 parents over their lifetime ranges between \$2.6 and \$3.2 billion in present value terms. Given that there is a new inflow each year, 


\section{MACROBUSINESS CONSULTING}

the accumulated taxpayer liabilities become very large over time. This is a high cost for a relatively small group.

Ultimately, every dollar spent on one social program must require either additional taxes or forgone government expenditure in other areas. It seems unlikely that parent visas meet the usual standards of proven need, in contrast to areas such as mental health, homelessness or, in the context of immigration, the support of immigrants through the humanitarian stream, and foreign aid.

Given the balance of the costs and benefits, the case for retaining parent visas in their current form is weak. ${ }^{88}$

Given the huge taxpayer cost of parental visas, and that these funds could be better spent elsewhere for the benefit of the incumbent population, there is a case for abolishing parental visas, which would lower Australia's intake by another 7,000 annually.

\section{Leave the humanitarian intake unchanged}

Australia's humanitarian migrant intake is already comparatively low at 16,250 in 201718 and has not shifted much since the turn-of-the-century. It is also budgeted to be lifted to 18,750 this financial year.

The humanitarian intake should remain at the current level.

In summary, by slashing the skilled migrant intake by 76,000 and reducing family visas by 7,000 , Australia could easily reduce the non-humanitarian permanent migrant intake back to around 75,000 .

With these settings, Australia would maintain a generous humanitarian intake and achieve exactly the same "skilled" intake that existed at the turn-of-the-century.

${ }^{88}$ PC. (2016). Migrant Intake into Australia. Productivity Commission Inquiry Report. No. 77. April 2016. https://www.pc.gov.au/inquiries/completed/migrant-intake/report/migrant-intake-report.pdf 